\title{
Conservar e amar o básico: um relato sobre a "inutilidade" fundamental da universidade*
}

\author{
Leonardo Rogério Miguel \\ Universidade Estadual do Norte \\ Fluminense Darcy Ribeiro \\ lrmiguel@uenf.br
}

Recebido em 10/09/2017

Aceito em 20/09/2017
Dedicado à Clara da Cruz Vidart Badia, brilhante estudante universitária e futura bióloga.
Penso que seja um truísmo afirmar que a Universidade deve ser uma experiência transformadora para os estudantes; não obstante, isto é algo que parece exigir constante ênfase. Sendo assim, sigo com truísmos e generalidades dignas de serem enunciadas. Meu objetivo é descrever de que maneira venho buscando chamar a atenção dos jovens estudantes (e dos não tão jovens assim) para os sentidos da experiência universitária. A meta da minha abordagem (aqui e atuando como professor) é revigorar certos significados e valores da ideia de universidade diante das pressões do tal "século XXI"1. Através desse objetivo, pretendo contemplar dois tópicos sugeridos na proposta deste dossiê, a saber: "o papel transformador da educação e da Universidade"; "a Universidade e seu dever para com a sociedade". Por sua vez, as perguntas-chave da exposição são: para que, e a quem as universidades deveriam servir no século XXI.

A exposição não traz novidades substanciais, em termos de diagnósticos ou prognósticos acerca da educação superior. A bem da verdade, recorre à informações e referências bastante conhecidas e difundidas, e à lugares-comuns também. Meus recursos são extraídos de variadas fontes, entre as quais estão as próprias constatações, convicções e queixas dos alunos. Também parto de minha própria experiência numa universidade específica, em um local e com condições específicos, em cursos e disciplinas específicas, com estudantes que apresentaram determinadas características e demandas em sala de aula e em conversas cotidianas. Ou seja, não tenho o objetivo de apresentar uma perspectiva precisa e

1 A expressão "século XXI" não tem um emprego genérico apenas cronológico, de demarcação ou referência a um período no tempo e na história do Ocidente. Entendo-a, aqui, como a designação de expectativas normativas sobre o presente e o futuro baseada em pressupostos ideológicos concernentes à uma concepção de progresso (moral, científico, tecnológico, dos costumes, etc), ou baseada em uma filosofia da história, segundo a qual o enredo do progresso é projetado e estabelecido por nós. Me refiro como "o tal século XXI" para ironizar as promessas e expectativas a respeito do momento em que vivemos agora. 
totalizante da vida acadêmica, embora esteja ciente de que cairei em contradição graças à minha tendência (inevitável) a projetar e a defender explicitamente aspectos de alguns modelos universitários em detrimento de outros. Lanço mão, deliberadamente, de tom informal, mais assertivo do que argumentativo. Convém ainda estabelecer que, nesta ocasião, desenvolvo minhas ideias tendo os estudantes em mente, especialmente aqueles que se encontram no primeiro ano de graduação, aqueles chamados de "calouros". As razões disso serão esclarecidas adiante.

\section{Generalidades e truísmos}

Os agentes promotores de transformações nos estudantes são tanto a instituição quanto os próprios, mas é um dever das universidades para com a sociedade proporcionar as condições para tais transformações, devendo exortá-las, orientá-las e valorizá-las. Quanto mais variados são os estudantes, mais diversos serão os modos e expressões das transformações, de modo que alguns parâmetros próprios à instituição precisam ser determinados seguindo alguns de seus valores fundamentais, tais como: o Conhecimento, o diálogo, o pensamento crítico, a liberdade, o respeito à diversidade, a cooperação. Qualquer experiência transformativa se dará através da lida com a produção, a preservação, a distribuição, a troca, a avaliação e reavaliação aberta e crítica dos diversos conhecimentos (requisitando os demais valores como uma condição sine qua non). Todo esse processo, sendo cultivado e ensinado aos estudantes, faz parte do caminho para mudanças individuais e coletivas que trouxeram e trazem benefícios para a sociedade.

Essa é uma descrição geral, comum e simples de um tipo idealizado de experiência que a Universidade (enquanto ideia ou conceito) deveria proporcionar a qualquer pessoa. Decerto, não são todos que vivenciam isso, seja por falta de acesso ao ensino superior ou por falta de interesse pelo mesmo. Para quem está dentro, a ausência da experiência transformativa pode ter como causa os próprios objetivos dos estudantes. A pessoa quer apenas receber o maior número possível de instruções profissionalmente úteis para sua atuação no mercado de trabalho. Isto é justo, admito. Uma outra causa pode ser o modelo da instituição - por exemplo, as faculdades dedicadas apenas ao ensino instrumental dos conteúdos específicos para formação em determinada área profissional. Essas causas, geralmente, estão correlacionadas, e não é o caso de se especular a respeito neste momento. O importante, aqui, é defender e apresentar algumas condições mínimas para que a Universidade seja uma experiência transformadora, pois é para isso que ela ainda deveria atender às expectativas da "sociedade global pós-industrial do século XXI". Para que tais condições sejam compreendidas, é necessário exortá-las.

Informações, conhecimentos, conceitos, esclarecimentos e franqueza sobre a Universidade e as universidades estão entre os elementos fundamentais que toda pessoa deve (e tem o direito de) adquirir em sua vida acadêmica, especialmente logo no primeiro ano de graduação. É mister que haja condições para pensar criticamente sobre o que foi adquirido e, em especial, para refletir e questionar sobre os modos como pensa sobre isso. Assim, também haverá condições para a pessoa pensar a respeito de seu papel, lugar e expectativas enquanto agente de sua formação.

Pode ser possível seguir na educação universitária alheio a isso tudo, basta estar familiarizado e ter a habilidade com os procedimentos burocráticos da graduação, tais como, por exemplo, o sistema de créditos, a inclusão e exclusão de disciplinas, a organização dos horários de estudos, os processos para pleitear bolsas de iniciação científica, de extensão e monitoria, ingresso em diretórios estudantis e centros acadêmicos. Entretanto, esse know how, embora de utilidade inquestionável (especialmente como maneiras de entender aspectos da vida acadêmica), pode não ser o bastante para a experiência transformativa e a formação integral, principalmente em universidades públicas. A compreensão do sentido da Universidade e do que seja fazer parte da vida do conhecimento é algo mais pessoal e profundo, é um compromisso nada trivial consigo mesmo e com a coletividade, a despeito da banalização das universidades como adestradora de mão de obra profissional e técnica de nível superior.

2 Para entender esses termos e por que fazem sentido quando colocadas juntas, sugiro a leitura de De MASI, 2017, pp. 479-496. 
Em virtude da referida banalização, os discursos sobre a Universidade abundam e há tantos especialistas em educação superior quanto técnicos de futebol em tempos de Copa do Mundo. Parece que todos sabem o que é Universidade, para que serve, a quem serve e como deve servir. Cada cabeça, um modelo e um propósito, mesmo no interior das próprias instituições. Tanto que uma das faces da "crise da Universidade" é o conflito entre modelos universitários. Como vivemos segundo uma narrativa econômica (neoliberal), acelerada e desesperada sobre o mundo, os cidadãos (contribuintes/clientes) demandam um modelo que prepare profissionais para o Mercado, gente apta aos empregos e "desafios do século XXI"3, capazes de empreender com eficiência, eficácia e excelência, ganhar salário suficiente para consumir, ser um membro padrão da sociedade erótico-publicitária, reproduzir valores mercadológicos e sua semântica própria, a fim de manter o Mercado estável em seu ciclo de produtividade e progresso. O que queremos mais do "tal século XXI"? Para a maior parte dos cidadãos, esse ciclo é "belo e moral", e é isso que querem para a sua prole. Afinal, é o que precisam para sobreviver, é isso que o país necessita, todos saem lucrando. É para isso e para as pessoas que hipervalorizam esse modo de existir que as universidades deveriam servir, dizem.

Não nego essas demandas e expectativas, tampouco as pressões dos tempos (pós-)modernos; porém, me recuso a limitar e reduzir o sentido da Universidade a esse papel. Por esse motivo, embora acredite que excelentes trabalhadores tenham que ser preparados com qualidade acadêmica e técnica nas universidades públicas (aliás, ainda é o melhor lugar para isso), defendo a preservação de valores, objetivos e tarefas aparentemente inúteis e ultrapassados (vítimas do "tal século XXI"), os quais vão de encontro à maioria dos discursos sobre a Universidade. Tais valores têm nas disciplinas filosóficas algumas de suas condições de possibilidade de difusão, assimilação e incorporação, mediante a oferta de, novamente, informações, conhecimentos, conceitos, competências, esclarecimentos e franqueza sobre a vida universitária e como explorá-la satisfatoriamente. E isso deve ser feito, repito, no primeiro ano da graduação.

Creio não ser difícil captar os motivos da minha atenção aos “calouros”, mas ofereço justificativas na próxima seção. Por ora, apenas adianto que meus objetivos enquanto docente e pesquisador são voltados para evitar a manutenção do seguinte quadro descrito pela professora de filosofia da USP Marilena Chauí:

\footnotetext{
Creio que a universidade tem hoje um papel que alguns não querem desempenhar, mas que é determinante para a existência da própria universidade: criar incompetentes sociais e políticos, realizar com a cultura o que a empresa realiza com o trabalho, isto é parcelar, fragmentar, limitar o conhecimento e impedir o pensamento, de modo a bloquear toda tentativa concreta de decisão, controle e participação, tanto no plano de produção material quanto no da produção intelectual (CHAUí, 2001, p.46)
}

Não é o caso de desmerecer nem de recusar as adaptações e transformações pelas quais a Universidade passou e passa desde, pelo menos, o século XIX. Me ocupo apenas em tentar equilibrar as demandas por mudanças com uma outra visão de Universidade, bem como apontar alguns conflitos e contradições entre modelos e interesses, os quais são geradores da(s) famosa(s) crise(s) da Universidade. De certa forma procuro inverter a escala de prioridades em voga entre governos, gestores de órgão de fomento, empresários, graduandos e seus familiares, e contribuintes de modo geral. Sendo assim, a princípio, não há a presunção de inventar um modelo que seja do agrado de todos os envolvidos com a vida e as missões das universidades, embora não deixe de tentar responder às perguntas normativas que me orientam. 


\section{De volta ao básico}

Seja nas disciplinas obrigatórias de introdução à Filosofia, seja em minhas disciplinas optativas sobre Universidade (e, mais recentemente, na disciplina instrumental sobre o estudo na universidade), em palestras ou conversas informais, costumo fazer as seguintes declarações aos alunos: (1) ser um professor de Filosofia em uma universidade pública que não conta com um curso de Filosofia me dá a vantagem de concentrar esforços na transformação de "números de matrícula" em estudantes universitários; (2) quaisquer planos de reforma universitária serão insatisfatórios enquanto as comunidades acadêmicas, os governos e a sociedade em geral carecerem de maior esclarecimento, compreensão e crítica conceitual sobre o que seja "Universidade", "Formação", "Ciência", "Crise", "Tecnologia" e "Inovação"; (3) sem um nível razoável de "conservadorismo universitário", as universidades brasileiras do século XXI alcançarão um nível de inutilidade que parecem almejar desde que se começou a questionar a utilidade das universidades.

Mais do que afirmações acerca dos meus valores e critérios a respeito da educação de nível superior e do papel da Filosofia na universidade (especialmente naquela em que trabalho), minhas posições são apresentadas aos alunos como hipóteses, proposições a serem esclarecidas e justificadas. Decerto, nesse processo didático-pedagógico, valores são explicitados, discutidos e sustentados através de literatura pertinente, assim como da troca de experiências e expectativas dos estudantes. Faço tais declarações a partir da perspectiva de um professor de Filosofia, cuja preocupação se dirige menos à mera instrução profissional e técnica do que à formação integral dos graduandos.

Nas próximas seções, apresento as maneiras como venho lidando, desde o ano de 2013, com o ensino e a pesquisa acerca das questões dos processos básicos de introdução à vida acadêmica (intelectual e científica) e sobre a Universidade, enquanto conceito e instituição.

\subsection{Constatação da urgência e medidas de enfretamento}

Minha primeira experiência docente efetiva, enquanto Professor Associado a ocupar uma das Cadeiras de História da Filosofia do Laboratório de Cognição e Linguagem (LCL/CCH-UENF), se deu no segundo semestre letivo do ano de 2013. Assumi a disciplina obrigatória "Filosofia" (prefiro chamar de "Introdução à Filosofia"), que compõe a grade curricular do curso de Administração Pública (Laboratório de Gestão de Políticas Públicas - LGPP/CCH). À época, a coordenação daquele curso estava reformulando seu projeto pedagógico e solicitou ao LCL a atualização da ementa de Filosofia. Como já havia sido acordado entre os professores de filosofia do LCL que eu seria o responsável pela disciplina, coube a mim a elaboração da ementa. Para tanto, procurei me basear naquilo que eu acreditava ser relevante para um estudante de Administração Pública: entender os diferentes modos de conceber a Filosofia, adotar atitude filosófica (reflexiva, questionadora, crítica, organizada e rigorosa), reconhecer o papel do pensamento filosófico em sua área de formação e, principalmente, ser capaz de ler, compreender e escrever ensaios filosóficos e textos acadêmicos em geral. Este último objetivo, a bem da verdade, é central para mim.

A ementa ficou simples, nada sofisticada; contudo, é satisfatória para os fins a que se propõe. Foi aceita pelo Chefe do LCL e pela coordenação do curso de Administração Pública. Confesso que tive dúvidas sobre a possibilidade de eu e a turma darmos conta da carga de leitura. A dúvida tornou-se certeza antes mesmo das aulas terem início. Eu não conhecia os alunos, não sabia o nível de maturidade intelectual e de disciplina de estudo deles. Ao conceber o programa do curso, eu tinha em mente o aluno de graduação em Filosofia, aquele que eu fui anos atrás. Pura ingenuidade, admito. Afinal, eu também era um docente "calouro".

Antecipei-me e procurei selecionar outros materiais de leitura. Restaram um livro e dois textos clássicos. Respectivamente, “A Filosofia: O que é? Para que serve?”, de Danilo Marcondes e Irley Franco (2011); "Apologia de Sócrates", de Platão, e "O valor da Filosofia", de Bertrand Russell. Incluí, após o início das aulas, o livro "A Ética da Virtude", de Stan Van Hooft (2013). No primeiro dia de aula, fiz uma exposição geral sobre a disciplina - dos objetivos à avaliação, passando por instruções sobre como aproveitar o curso. Ofereci também instruções de como ler e fichar textos. Para descobrir o que aqueles jovens entendiam por Filosofia, elaborei um questionário. Transcrevo as perguntas: 
(a) O que eu, , entendo por "Filosofia"?

(b) Qual é a importância disso que eu entendo por "Filosofia" para a minha formação acadêmica e profissional?

(c) Por que os responsáveis pelo curso de bacharelado em Administração Pública teriam dado um lugar para a Filosofia na grade curricular obrigatória?

(d) O que espero desta disciplina, como posso aproveitá-la ao máximo e por que eu deveria me dedicar?

As respostas foram entregues na segunda aula.

Como primeira avaliação semestral, os alunos deveriam redigir um texto argumentativo respondendo as mesmas perguntas após a metade do curso. Ou seja, o objetivo era demonstrar que haviam aprendido alguma coisa até aquele momento e que tinham exercitado o modelo de leitura oferecido a eles. $\mathrm{O}$ resultado foi frustrante para mim. A maioria da turma apresentou problemas de expressão escrita, especialmente em termos de composição de frases, de coerência e coesão entre os parágrafos, de argumentação básica. Era urgente "ensiná-los a escrever" e impor um treinamento. Diante disso, interrompi a sequência original do curso e parti para o "segundo módulo" do programa, a fim de que os resultados da avaliação final fossem melhores.

A terceira avaliação (a final) foi a redação de um ensaio de cunho filosófico, um texto argumentativo sobre um tema da escolha de cada um. Sugeri que selecionassem um tópico relacionado à Administração Pública e/ou à Filosofia. A partir desse momento do curso, enfatizamos a leitura do livro "Construção do Argumento" (2006), de Anthony Weston. Além disso, acompanhei a composição dos textos. Os mais dedicados escreveram esboços e os apresentaram. Alguns foram até o meu gabinete para dirimir dúvidas e pedir sugestões. Foi como, de repente, ter nas mãos treze orientandos.

Ao finalizar as correções, não pude negar que houve progressos nos resultados dos estudantes. No entanto, mais de dois alunos ficaram insatisfeitos com as notas e com minhas críticas severas, pois acreditavam que mereciam mais pelo esforço que haviam dedicado. Daí, percebi outro problema (óbvio, mas que me escapou ao longo do curso): eles também não tinham por hábito avaliar a si próprios, para distinguir entre um texto escrito de forma aceitável academicamente, um texto mal escrito e uma compilação de frases e citações alheias com pouco sentido (falta de coesão e coerência provocando uma "colcha de retalhos" textual). Conversando com outros professores, constatei que o problema estava generalizado: do início ao fim da graduação, chegando até o mestrado (sim, acredite), muitos alunos seguiam sem a capacidade de ler, analisar, compreender, interpretar textos acadêmicos; tampouco mostravam habilidade para escrevê-los nem, tampouco, para avaliar sua própria competência. Era (é) urgente dirimir essa falha. A tarefa de dirimir o "semianalfabetismo funcional acadêmico" é uma prioridade.

Convém ser honesto e admitir que eu estive no lugar dos meus estudantes até o quinto período da graduação em Filosofia na UERJ. Um dos professores que mais influenciou minha formação afirmou sumariamente: "você escreve muito mal". Ele entregou um dos meus textos com várias marcações de revisão e anotações em vermelho. Até aquele momento, embora escrever exigisse um esforço tremendo, eu não detectava problemas consideráveis na minha redação. A palavra daquela respeitável autoridade abriu meus olhos e me tornou obcecado, não apenas com a "escrita perfeita", a construção do argumento, mas também com a metodologia filosófica, com as formas de ler, analisar, explicar, comentar e dissertar academicamente.

Importante advertir que tal obsessão pelo perfeccionismo é deletéria, provoca receios, paralisa e atrapalha o fluxo do trabalho; digo isso por experiência própria. Não obstante, é desnecessário dizer que o exercício e o aprimoramento do raciocínio e da argumentação lógica, bem como da escrita clara e precisa, devem ser constantes, principalmente para desenvolver a medida e o controle do que seja a perfeição.

A fim de dar conta da tarefa, o "segundo módulo" de "Introdução à Filosofia" tornou-se a disciplina optativa "Tópicos Especiais em Filosofia: construção do argumento e lógica informal”, oferecida no primeiro semestre letivo de 2014. A disciplina se baseava na concepção bastante corriqueira, a de que escrever e avaliar argumentos são práticas fundamentais para uma sólida formação universitária. Seja para ler e discutir textos 
acadêmicos, seja para produzi-los (resenhas, fichamentos, monografias, artigos e dissertações) de maneira crítica, organizada e clara, o estudante precisa dominar as técnicas da argumentação. Enfatizo que a proposta se originou da constatação de que a ausência de instrução mínima acerca das técnicas responde por uma parcela significativa dos resultados insatisfatórios, das frustrações e das inseguranças dos estudantes universitários. Tendo isso em vista, é urgente introduzir o estudo do pensamento crítico, da redação argumentativa e da lógica nos primeiros anos da vida acadêmica.

O público-alvo da disciplina não se restringiu aos estudantes do Centro de Ciências do Homem. Afinal, repito, compreender, avaliar e escrever argumentos são práticas imprescindíveis para a formação integral de qualquer estudante universitário. Assim sendo, conforme diz o título do curso, o objetivo foi proporcionar uma introdução às regras de construção do argumento e à lógica informal.

Obtive resultados nada extraordinários, apenas regulares (havia sete alunos matriculados). Não obstante, posso fazer uma breve autoavaliação (bastante parcial). Creio não ter sido capaz de motivar os alunos a estudarem e a incorporarem o conteúdo dos livros mencionados. Talvez isso tenha ocorrido em virtude de limitações didáticas (pouca experiência como docente, pouca competência) e da dificuldade para organizar o conteúdo apresentado. Estava (e ainda estou) em fase experimental com esse tipo de curso.

Em 2015, tive a oportunidade de conduzir o mesmo curso com um colega docente em um programa da pós-graduação do $\mathrm{CCH}$. Embora prefira me ocupar com os graduandos, em pouco tempo de casa, fui informado de que os pós-graduandos apresentavam as mesmas dificuldades de escrita. Diante disso, um fator-chave para a instauração da disciplina na pós-graduação foi o visível declínio da qualidade dos mestrandos e doutorandos em virtude do rebaixamento dos critérios de aprovação e do "afrouxamento na qualidade da formação dos pesquisadores futuros" " (FreITAS, 2007, p.190). Cabe fazer um comentário sobre esse problema.

Os critérios de avaliação acadêmica empregados atualmente são deletérios e inócuos. Vivemos tempos de "quantificação" e supervalorização da produtividade, pois os "órgãos superiores" (que regulam a atividade acadêmica) e seus agentes já estão esgotados intelectual e fisicamente para dar conta da massa de produções científicas (decerto, esta não é a única razão para adotar a avaliação atual). Lança-se mão de softwares para análise de dados. Em geral, o "ranking" é feito com base na quantidade de produções e citações, pouco importando o conteúdo das mesmas. O importante é massificar e gerar números, em detrimento da qualidade dos produtos gerados pelas pesquisas.

Por sua vez, as credenciais acadêmicas perdem o peso de outrora, de modo que não basta o sujeito ser bacharel/licenciado para ser valorizado no mercado de trabalho, é necessário "pós-graduar-se". O bacharel/ licenciado precisa de "especialização" ou mestrado para ascender um tanto mais na carreira; as universidades precisam formar ("fabricar"?) um certo número de mestres e doutores para "cumprir metas" (ou ter lucro, no caso das universidades particulares). Parece que o raciocínio para a aprovação nas pós-graduações é o seguinte: "Ora, por que não facilitar as coisas e irmos ao encontro dos interesses da universidade e do aluno em potencial?". Essas circunstâncias elevam a urgência da dedicação à formação dos graduandos, mas não exatamente apenas para atender aos critérios produtivistas e mercadológicos envolvidos nas seleções e avaliações dos programas de pós-graduação.

\section{Sobre vieses cognitivos e a saúde mental dos estudantes}

Além dos problemas de leitura e redação, outros fenômenos sempre me chamaram a atenção, tais como os tratos interpessoais no cotidiano acadêmico. Como as pessoas que vivem a vida acadêmica lidam umas com as outras, especialmente com aquelas sem as mesmas credenciais acadêmicas que elas? No caso do curso de Filosofia, me perguntava se elas tratavam aos outros e a si mesmas com sabedoria. De um modo geral, como isso afeta a todos os envolvidos?

4 Pressupondo que os aprovados nas pós-graduações estejam interessados em seguir a vida acadêmica, e não apenas preocupados com o retorno financeiro de suas titulações. 
Ainda entre os anos de 2014 e 2015, elaborei e orientei uma pesquisa de Iniciação Científica cujo título original era "Tendências cognitivas na formação e nas relações acadêmicas: uma análise teórico-conceitual preliminar". A ideia era conciliar meus interesses antigos sobre as relações entre epistemologia e ética na formação e na atividade científicas e suas inter-relações no seio da universidade (abordagens à luz de estudos filosóficos, históricos e sociais sobre a ciência). Através daquela pesquisa, procurei conciliar aqueles interesses com os mais recentes, que são as dificuldades no aprendizado e na transmissão de conhecimentos, bem como nas relações interpessoais, proporcionadas pelas tendências cognitivas, heurísticas e falácias lógicas, com foco especial na vida acadêmica. Concebo ambos os temas como interligados, sendo o segundo um desdobramento do primeiro.

Tendo isso em vista, o propósito inicial da pesquisa foi tematizar e problematizar as condições das trocas epistêmicas (relativas ao conhecimento que se busca, se ensina e se difunde) no cotidiano da vida acadêmica, especialmente fora das salas de aula, diante daquela (quase) inescapável tríade de conceitos da Psicologia Cognitiva, recapitulando: tendências cognitivas, heurísticas e falácias lógicas.

\subsection{Questões cognitivas e psicológicas}

Não tenho formação em psicologia; porém, acreditava que a minha experiência em epistemologia e filosofia da ciência pudesse estabelecer alguma interseção entre os campos de investigação. Afinal, "falácias lógicas" e "heurísticas" são termos comuns na Filosofia. Por sua vez, "tendências cognitivas" também são próximos da epistemologia e da ética, pois designam modos peculiares de se pensar, abraçar crenças, tomar decisões, agir e se comportar. Assim sendo, tinha um trabalho de natureza interdisciplinar nas mãos.

A premissa básica dizia que determinados comportamentos, valores e traços de caráter relativos aos modos de se pensar, produzir, sistematizar e transmitir o conhecimento estão intimamente ligados às maneiras como fazemos julgamentos e escolhas, supostamente, racionais. Em outros termos, no cotidiano universitário, a epistemologia (o estudo filosófico sobre o conhecimento) encontra a psicologia cognitiva em forma de tendências cognitivas, heurísticas e falácias lógicas, seja nas salas de aula, seja nos corredores e nos gabinetes. A pergunta em jogo era a seguinte (enunciada da forma mais simples): "o que os membros da comunidade acadêmica devem saber e exercitar a fim de evitar conflitos intelectuais gerados por fenômenos psicológicos e cognitivos, tendo em vista que esses conflitos influenciam as relações interpessoais dentro de uma instituição de grande relevância social?". A hipótese era a de que, para dirimir tais problemas, seria interessante e profícuo a obtenção de algum domínio dos termos, conceitos e teorias comuns à epistemologia e à psicologia cognitiva, tais como: "crença", "ceticismo", "virtudes intelectuais", "dissonância cognitiva" e, especialmente para os nossos fins, "tendências cognitivas", "heurísticas" e "falácias". Tão importante quanto estar familiarizado com esses termos é entender suas influências em nossos pensamentos.

As intenções da proposta eram mostrar como a Epistemologia e a Psicologia Cognitiva determinavam os sucessos ou os fracassos nas relações e nas atividades básicas da vida acadêmica, e, seguindo as intenções pedagógicas do psicólogo norte-americano Daniel Kahneman, oferecer ferramentas conceituais e teóricas para "aperfeiçoar a capacidade de identificar e compreender erros de julgamento e escolha, nos outros e afinal em nós mesmos, propiciando uma linguagem mais rica e mais precisa para discuti-los" (KaHNemAn, 2012, p.11). Sendo assim, foram estabelecidos como objetivos específicos a realização de uma análise preliminar das tendências cognitivas, heurísticas e falácias mais corriqueiras e a avaliação da maneira como são capazes de influenciar o cotidiano da vida universitária, em especial no que tange as relações e comportamentos epistêmicos e pedagógicos, isto é, que envolvem pesquisa, ensino e extensão.

A investigação foi realizada por uma estudante da graduação ${ }^{5}$, e decidi delimitar a pesquisa seguindo o trabalho que ela havia realizado na disciplina "Introdução à Filosofia" no segundo período do ano letivo de 2013: "O Efeito Dunning-Kruger na Administração Pública”. Logo, a pesquisa direcionou-se para a área de interesse da estudante, a Administração Pública, mas não perdeu sua intenção central: parafraseando

5 Agradeço à Júlia Vieitas Sarruf Alhanati, minha ex-orientanda e, hoje, bacharel em Administração Pública, pela colaboração na primeira etapa da pesquisa. 
Kahneman novamente, oferecer ferramentas conceituais e teóricas para "aperfeiçoar a capacidade de identificar e compreender erros de julgamento e escolha, nos outros e afinal em nós mesmos, propiciando uma linguagem mais rica e mais precisa para discuti-los" além das salas de aula, ou seja, "para o bate-papo do cafezinho" (p.11), para os corredores e pátios da UENF.

Em virtude das limitações de tempo, restringimos o tema às tendências cognitivas; tendo como tópico a condição de ignorância em relação à própria ignorância e a estimativa de seus possíveis efeitos na gestão de políticas e de organizações públicas. O Efeito Dunning-Kruger, também chamado de Efeito de Superioridade Ilusória, é a expressão empregada para designar a ignorância, a incapacidade, a inconsciência ou falta de habilidade das pessoas em reconhecer a própria incompetência e seus erros, bem como em estimar a dificuldade de tarefas e atividades nas quais estão envolvidas.

Construímos nosso tema e nossa problematização a partir de fatos, situações e condições dos cotidianos institucional e político, entre os quais está a possibilidade de sermos incapazes de reconhecer nossos próprios erros e nossa incompetência em determinados cargos e tarefas. Por exemplo, quem nunca teve de lidar com pessoas indicadas para bons cargos que não demonstravam qualquer adequação para a posição, mas que, a despeito disso, mantinham a pose e se vangloriavam dos resultados de suas tarefas (resultados alcançados graças a seus subordinados mais competentes)? Certamente, nós também já estivemos nesse lugar - inaptos e com resultados desastrosos ou abaixo da média; porém, confiantes, vaidosos e egocêntricos, alheios à realidade. Conforme declarado no título de uma publicação eletrônica do psicólogo americano David Dunning, somos todos idiotas autoconfiantes (DunNing, 2014). Com aquele título, Dunning não estava tentando ser jocoso ou polêmico; estava relatando uma constatação (de cunho tanto científico quanto de senso comum) e apontando como um problema as condições psicocognitivas e situações que, geralmente, tomamos como sendo triviais e até mesmo cômicas.

Piadas à parte, o certo é que a condição de ignorância pode ser vivenciada por qualquer um de nós em quaisquer momentos e fases da vida. A dificuldade (o ponto cego da cognição) está em saber (ou reconhecer) que estamos iludidos a respeito de nossas crenças, opiniões, habilidades e competências. Em outros termos, de início e na maioria das vezes, a metacognição não é o forte de nossa espécie. Dito isto, o problema que encaramos está em como detectar e lidar com tendências cognitivas, heurísticas e falácias lógicas no cotidiano das instituições e organizações públicas. A pesquisa foi uma modesta contribuição na busca de respostas.

\subsection{Metaignorância}

Basta uma rápida inspeção de nossos tratos cotidianos para inferirmos que a incompetência e a ignorância campeiam e são condições perigosas. É suficiente prestar atenção aos jornais e à rotina das nossas instituições para constatar que, com uma regularidade perturbadora, os incompetentes estão no comando e tomando decisões ruins sobre casos de relevância social. Como isso é possível? Por que isso é tão comum? Por que, afinal, as pessoas mais ignorantes são as que têm mais confiança em suas próprias opiniões notoriamente equivocadas? Sugestões para potenciais respostas podem ser encontradas através do entendimento sobre o que são tendências cognitivas, heurísticas e falácias lógicas.

Segundo o psicólogo e divulgador científico David McRaney, tendências cognitivas (ou vieses cognitivos) ${ }^{6}$ são "padrões previsíveis de pensamento e comportamento que o levam a tirar conclusões [precipitadas] e incorretas... [são] formas desagradáveis e completamente errôneas de ver as coisas..." (McRANEY, 2012, p. 12). Por sua vez, o psicólogo Daniel Kahneman define como "erros sistemáticos [...] e se repetem de forma previsível em circunstâncias particulares" (2012, p.10). Ele usa a expressão "vieses da intuição" para designar aquilo que conhecemos como preconceitos, tendências, propensões e inclinações. Cada uma dessas manifestações dos vieses da intuição expressa padrões deturpados e equivocados de apreensão, avaliação e julgamento daquilo que seja o caso (ou da realidade, se preferir). Desse modo, tendências cognitivas atuam quando construímos inferências e juízos sobre, por exemplo, outras pessoas e seus modos de vida sem qualquer base lógica. Desnecessário dizer que a ocorrência desse fenômeno tem potencial para gerar sofrimento

6 A expressão inglesa cognitive bias também é traduzida como "vieses cognitivos". Uso ambas as traduções. 
e morte. Kahneman, à guisa de ilustração, compara os vieses à cegueira. Ele escreve que, em determinadas circunstâncias, "podemos ficar cegos para o óbvio e também cegos para a nossa própria cegueira" (2012, p.33). Em outros termos, a "cegueira generalizada" é uma das dificuldades para avaliar e pensar sobre o que consideramos ser a realidade, assim como sobre os acontecimentos, os nossos comportamentos e ações, e sobre o próprio pensar (metacognição).

A heurística, por sua vez, deriva do célebre verbo grego "heúreka" (lembre-se do "eureca" de Arquimedes: "Eu descobri!"), ou mais exatamente da palavra grega heurisko - "eu descubro" (FRENCH, 2009, p.31). Entretanto, em nossos dias, a heurística designa menos um "lampejo de gênio" (os supostos insights de Arquimedes dentro da banheira e a maçã de Newton, por exemplo) do que os modos, abordagens e métodos empregados por alguém para chegar à resolução de um problema mesmo que não tenha em mãos as informações completas sobre o que seja o caso. Segundo Kahneman, heurística é "um procedimento simples que ajuda a encontrar respostas adequadas, ainda que geralmente imperfeitas, para perguntas difíceis" (KaHneman, 2012, p. 127).

$\mathrm{Na}$ metodologia científica, a teoria da probabilidade e a estatística fazem parte dos procedimentos heurísticos. Ambos os recursos matemáticos oferecem algum rigor às heurísticas. Não obstante os rigores, a adoção da heurística ficou mais "popular" como aquilo que Kahneman chama de "heurística simplificadora": "método de investigação com base na aproximação progressiva de um problema, de modo que cada etapa é provisória" (2012, p.14). Por sua vez, o filósofo da ciência Steven French diz que "uma heurística está em algum lugar entre a formalidade límpida da lógica e o lampejo aparentemente caótico e irracional da inspiração" (FRENCH, 2009, p. 32).

Entretanto, a filosofia e a metodologia científica não integram regular e efetivamente os nossos raciocínios cotidianos. Sendo assim, em termos não tão acadêmicos, porém mais incisivos, entendemos heurísticas como

atalhos mentais que você usa para resolver problemas triviais. Elas aceleram o processamento no cérebro, mas, às vezes, o levam a pensar tão rápido que você se esquece do mais importante. Em vez de pegar o caminho longo e contemplar profundamente o melhor curso de ação ou a cadeia de pensamento mais lógica, você usa heurísticas para chegar a uma conclusão em tempo recorde. [...] Quando elas funcionam, ajudam a sua mente a permanecer frugal. Quando não, você vê o mundo como um lugar muito mais simples do que realmente é (McRaney, 2012, p.12. Grifos meus).

Eis um exemplo comum de um caso de simplificação da realidade via heurísticas: "se você nota um aumento nas notícias de ataques de tubarão nos jornais, começa a acreditar que os tubarões estão fora de controle, quando a única coisa que você sabe com certeza é que os jornais estão veiculando mais histórias sobre tubarões do que o normal" (Idem. Grifos meus).

Quando se emprega um "atalho mental" equivocado e chega-se a uma conclusão em que o mundo se apresenta como "um lugar mais simples do realmente é", costuma-se expressar a crença (falsa) resultante daquela conclusão através da linguagem. Formula-se um argumento contendo premissas que explicam e tentam defender a tal conclusão. Grosso modo, premissas devem informar sobre os fatos que podem dar sustentação (razão) à conclusão. Tendo em vista o "tempo recorde" em que se chegou à conclusão, bem como a "simplicidade" do que seja o caso, as premissas do argumento serão tão suspeitas quanto a conclusão apressada. Nessas condições, é muito provável que se lance mão de falácias lógicas para tentar salvar o "mal funcionamento do atalho mental". Nas palavras contundentes de McRaney, a tal conclusão é enunciada porque as inferências que levaram a mesma brotaram "sem levar em consideração todos os fatos", e mais: "porque você não se importa em ouvi-los [os fatos] ou não tem ideia de quão limitada é a sua informação" (p.13). Não é incorreto observar que, provavelmente, você tampouco pode ter noção de quão limitada é a sua capacidade de reconhecer, entender, analisar e avaliar informações (sinais do "Efeito Dunning-Kruger", conforme veremos). Em suma, falácias lógicas são raciocínios incorretos, erros e táticas enganosas de tentar mostrar que se está com a razão e ganhar a discussão na marra.

Todos nós estamos propensos a falsas especulações, a nossa mente é composta por noções preconcebidas 
e padrões de pensamentos incorretos (em outros termos, tendências cognitivas). E o pior: nós raramente percebemos isso, de modo que vivemos iludidos. Cito McRaney: "A verdade é que há um crescente corpo de trabalhos no campo da psicologia e ciência cognitiva que afirma que você não tem nenhuma noção de por que age, escolhe as coisas que escolhe ou pensa os pensamentos que pensa". (McRANEY, 2012, p.9). Por exemplo, quando, lá em cima, você leu a pergunta "por que, afinal, as pessoas mais ignorantes são as que têm mais confiança em suas próprias opiniões notoriamente equivocadas?”, decerto não se incluiu no grupo de "pessoas mais ignorantes". Isso acontece porque você acredita que está no grupo de "pessoas acima da média"; logo, suas opiniões são sempre inteligentes, embasadas e confiáveis. Além disso, ignorantes, feios, desonestos são os outros, nunca você. Você foi programado para descartar juízos negativos a seu respeito e identificar a si mesmo apenas com palavras positivas e elogios. Temos três tendências cognitivas em ação aqui: "Efeito Acima da Média", "Efeito da Terceira Pessoa" e "Viés da Confirmação". Não falarei sobre estes nesta ocasião.

McRaney nos diz que as tendências cognitivas são responsáveis por levantarmos da cama todos os dias. Isto quer dizer que considerar-se entre os que estão "acima da média", embora não tenha justificativas para isso, e atribuir deficiências e defeitos apenas aos outros (ou a qualquer coisa que não seja você) são exemplos do lado positivo das tendências cognitivas. A despeito de serem atitudes baseadas em ilusões, demonstram a grande saúde de nossa autoestima.

Muitas delas [tendências cognitivas] servem para mantê-lo confiante nas suas próprias percepções ou para inibi-lo de ver a si mesmo como um bufão. A manutenção de uma autoimagem positiva parece ser tão importante para a mente humana, que você desenvolveu mecanismos mentais projetados para se sentir ótimo com relação a si mesmo. (McRANEY, 2012, p.12).

Sentir-se ótimo não obstante as decisões, crenças e ações equivocadas que podem advir de nossa "autoimagem positiva”. De qualquer modo, no limite, é razoável concordar com McRaney e concluir que viver iludido é uma condição para a sobrevivência humana. Em outras palavras, há ilusões das quais não podemos abrir mão. Apesar dessa condição, a situação se torna menos confortável quando nos dirigem perguntas assim: o que te leva a crer que é alguém "acima da média", e não um ignorante? Você é capaz de ouvir o outro falar francamente sobre suas imperfeições? És capaz de realizar uma autoavaliação com profundidade e honestidade?

São questionamentos dessa natureza, bem como os esforços para respondê-las crítica e reflexivamente, que tentam deter as consequências negativas de predisposições, crenças e ações assentadas tão somente em tendências cognitivas, em ilusões. Uma vez afirmadas a persistência e a relevância das ilusões cognitivas para a nossa existência, cabe, então, continuar a tarefa de identificá-las, nomeá-las, compreendê-las e divulgá-las.

O Efeito Dunning-Kruger, ou Efeito de Superioridade Ilusória, representa nossa dramática ambivalência em relação às ilusões cognitivas. Por um lado, nos faz levantar da cama todos os dias, mantém nossa autoestima em níveis salutares, protege e consola nossos egos, simplifica e torna aceitável as complexidades do mundo real. Por outro lado, como diz David Dunning, nos torna idiotas confiantes, presunçosos, arrogantes, irresponsáveis e patéticos. Além disso, tem potencial para comprometer carreiras profissionais, organizações, empresas e governos, porque, nas palavras de Miguel Braga (2011), "a inconsciência da incompetência das "vítimas" do Efeito Dunning-Kruger provoca um círculo vicioso, pois elas deixam de tomar medidas de autoaperfeiçoamento, continuando incompetentes e incapazes de melhorar". Apesar disso, pelo fato de fazer parte de nossos mecanismos de sobrevivência, esse "distúrbio cognitivo" está tão enraizado em nós quanto a medula óssea.

Embora Dunning e Justin Kruger tenham realizado os experimentos para definir o problema e provar suas hipóteses (ver adiante), inspirando, assim, um nome para o fenômeno, a "ignorância da ignorância" e suas consequências já haviam sido identificadas por vários filósofos e cientistas ao longo de quase 2500 anos. Por exemplo, a famosa frase de Sócrates - "Só sei que nada sei" - era uma maneira irônica de instigar seus concidadãos a reconhecerem e questionarem a própria ignorância, a se dedicarem ao autoconhecimento, a 
retirarem a venda dos olhos e seguirem na busca humilde e profunda do verdadeiro conhecimento. Diante disso, não seria incorreto afirmar que Sócrates ${ }^{7}$ tenha sido o primeiro filósofo (da História da Filosofia Ocidental) a identificar e tentar combater a "metaignorância" (HuANG, 2013, p.415), condição em que não sabemos que nada sabemos.

É muito importante esclarecer que não concebemos o ignorante como um "cabeça de vento", uma tábula que se mantém rasa por vontade própria. Pelo contrário, seguimos a caracterização da "mente ignorante" segundo David Dunning, a saber: a mente ignorante encontra-se "preenchida por uma confusão de experiências de vida irrelevantes ou equivocadas; teorias, fatos, intuições, estratégias, algoritmos, heurísticas, metáforas e palpites que, lamentavelmente, têm a aparência e sensação de conhecimento útil e apurado" (DunNing, 2014, s/p). ${ }^{8}$

Há mais dois exemplos - deliberadamente anacrônicos - de pensadores que deixaram seus comentários sobre o comportamento de quem "sofre" do Efeito de Superioridade Ilusória". Atribui-se ao naturalista inglês Charles R. Darwin a seguinte frase: "A ignorância com mais frequência que o conhecimento gera confiança". Ou seja, por ser incapaz de fazer uma autoavaliação, o ignorante segue confiante em seus planos para ocupar postos de relevância na sociedade. Afinal, ignorantes não são necessariamente ingênuos, nem desprovidos de outros artifícios para se imporem e ganharem influência. Ignorância não exclui habilidades verbais e sociais. A frase atribuída a Darwin parece expressar sua preocupação quanto ao tipo de personalidade e comportamento dos confiantes. Estes podem ser mais assertivos e ativos do que aqueles que buscam o conhecimento e o autoconhecimento. Ignorantes confiantes demonstram mais conviç̧ão nos gestos e nas palavras, já que não duvidam de si mesmos. Em suma, ignorantes confiantes podem ser muito carismáticos, embora sejam autocentrados e indiferentes às outras pessoas e às suas opiniões (não necessariamente em virtude de abissal idiotia, mas por acreditarem ser superiores).

Se Darwin foi mesmo o autor da frase, ousamos supor que ele tinha em mente a sua própria personalidade ao estabelecer o contraste entre ignorantes confiantes e investigadores. Ademais, o background de sua declaração era a oposição barulhenta e pouco esclarecida que sua teoria biológica da evolução das espécies enfrentava (nem seus apoiadores entenderam tão bem a teoria). Como bom investigador que era, Darwin estava ciente do quão difícil é elevar crenças e hipóteses ao estatuto de conhecimento. Para provar uma hipótese, é preciso elaborar os métodos, encontrar, revisar e avaliar os dados, justificar o uso de determinados dados como evidências. Obter conhecimento é algo muito custoso, exige paciência, atenção, mente aberta, atitude cética, espírito de grupo e desapego, porque o preço a se pagar pelo progresso da ciência é a transformação de "conhecimentos" em meras crenças.

Essas e outras características, geralmente, fazem daqueles que buscam conhecimento pessoas mais cautelosas e céticas em relação àquilo que experienciam, afirmam e acreditam, são mais propensas à autoavaliação e à crítica dos procedimentos adotados. Somadas ao caráter provisório do conhecimento, as qualidades supracitadas proporcionam a impressão de que o discurso do pesquisador é hesitante, incerto e pouco confiável aos ouvidos do público leigo. Nesse sentido, a confiança e a convicção dos ignorantes prevalecem no gosto popular, pouco importando a adequação das ideais aos fatos, nem o confronto com a crítica. Para ilustrar essa situação, lançamos mão de uma citação atribuída ao filósofo inglês Bertrand Russell: "No mundo moderno, os estúpidos estão cheios de certezas enquanto os inteligentes estão cheios de dúvidas" (esta frase também é atribuída ao escritor norte-americano Charles Bukowski). Não seria equivocado supor que essa observação de Russell (ou de Bukowski) tenha sido inspirada na de Darwin.

7 Aceitamos, deliberadamente, o risco de incorremos em anacronia.

8 Interpretamos as citações famosas que virão segundo a descrição acima; logo, ela vale para tanto para o "ignorante”, quanto para o "estúpido" e o "idiota”. 


\subsection{Incorporando os resultados: uma hipótese geral sobre o estado dos jovens estudantes}

Como se os problemas de expressão escrita já não fossem ruins o bastante na vida universitária, no ano de 2016, passei a me familiarizar com as queixas de ordem psicológica dos discentes. Travei contato com isso da maneira mais corriqueira: conversas informais nos primeiros quinze minutos das aulas de Filosofia para o curso de Licenciatura em Pedagogia. E tudo começava com a pergunta: “como vão vocês?". As expressões de desânimo e as queixas abundavam.

Como os conteúdos e o método da Filosofia tratam de várias questões existenciais e exigem que as alunas e os alunos empreguem reflexões e questionamentos que colocam em jogo suas subjetividades e relações com questões cotidianas que, antes, pareciam simples, o aparecimento de dúvidas e angústias são bastante comuns. Daí, o passo para o aparecimento de exemplos e queixas pessoais é bem curto. Quadros de ansiedade crônica, depressão, ideações e tentativas de suicídio pululam entre estudantes universitários no Brasil ${ }^{9}$. Assim como pós-graduandos e professores-pesquisadores das universidades brasileiras sofrem com as pressões por produtividade acadêmica em acelerada escala industrial (além de terem que lidar com o ensino, a extensão e a lida administrativa de suas instituições) ${ }^{10}$, os estudantes carregam consigo sofrimentos gerados ou disparados por questões acadêmicas ${ }^{11}$. Parte disso também tem a ver com o Efeito Dunning-Kruger. Ou melhor, com o seu avesso.

O efeito de superioridade ilusória foi descrito a partir dos resultados de testes realizados pelos psicólogos David Dunning e Justin Kruger. Os resultados foram publicados em 1999. O título do artigo é Unskilled and Unaware of It: How Difficulties in Recognizing One's Own Incompetence Lead to Inflated Self-Assessments (traduzimos como "Sem talento e sem noção: como as dificuldades para reconhecer a própria incompetência levam à autoavaliações exageradas"). Em 2008, foi publicado um artigo cujo objetivo era revisar os experimentos e os resultados apresentados em 1999. Seu título é Why the unskilled are unaware: Further explorations of (absent) self-insight among the incompetent ("Por que os desprovidos de talento são sem noção: maiores explorações sobre a (ausência) de autopercepção entre os incompetentes”). Os autores Joyce Ehrlinger, Kerri Johnson, Matthew Banner tiveram a intenção de testar explicações alternativas para o Efeito Dunning-Kruger; porém, chegaram a conclusões idênticas as do trabalho original. A novidade exposta no artigo é a caracterização da Síndrome do Impostor.

"Síndrome do Impostor" ou, originalmente, "Fenômeno do Impostor" já havia aparecido na literatura científica desde o final da década de 1970 (ClanCE; IMES, 1978) ${ }^{12}$. À época, a pesquisa que colocou esse sentimento em voga afirmava que era algo mais comum entre as mulheres. Entretanto, pelo que pude constatar, penso que o caso não seja tão restrito assim a um gênero. Podemos dizer, que a Síndrome do Impostor seja a versão do Efeito Dunning-Kruger para pessoas com baixa autoestima e tendência à depressão. Uma pessoa muito insegura pode duvidar de sua própria competência profissional, avaliando-se como uma fraude ou incapaz de desenvolver corretamente determinadas tarefas, não merecedor dos elogios e dos sucessos que atinge. Essa impressão pode ser oriunda da própria atividade metacognitiva do "impostor" em conjunção com sua humildade intelectual; todavia, há exageros na maneira como a pessoa lida com esses fatores.

O “impostor" não se caracteriza tanto como um idiota, mas também pode demonstrar deficiências de habilidade metacognitiva. A idiotia pode ser detectada se o "impostor" se mostra incapaz de pôr de lado sua autoimagem negativa para ouvir o outro e levá-lo a sério. Talvez, essa deficiência seja provocada pela personalidade, por vezes, insegura e autossabotadora do "impostor" (seria um caso mais severo do que anterior), e não tanto por inabilidade metacognitiva. Porém, se for por este o caso, a personalidade dos "impostores" irá prejudicá-lo ainda mais, especialmente se conviver com idiotas autoconfiantes.

9 Cf. Cerchiari, 2005; De Melo Cavestro; Rocha, 2006; Dutra, 2012.

10 Cf. Mendonça, 2014.

11 Há uma série de outros fatores emocionais, bem como sociais, que provocam sofrimento (ou adoecimento) psíquico nos estudantes. Condições de saúde mental prévia não diagnosticadas, distância da família, dificuldade para se adaptar à mudança de cidade, dificuldades financeiras, entre outros. O leitor verá que minha preocupação não se volta diretamente a estes fatores.

12 Para uma visão geral: Impostor Phenomenon. Disponível em: https://www.youtube.com/watch?v=yXK3zNHYUrI Acessado em 05 de setembro de 2017. 
Idiotas superestimam as próprias competências; "impostores" subestimam as suas. Idiotas autoconfiantes não reconhecem competência/habilidade de outras pessoas; "impostores" não reconhecem as suas próprias. "Impostores" tendem a subestimar seu "grau de adequação" (Efeito de Falso Consenso); idiotas não reconhecem "o grau extremo de sua inadequação". Observa-se que essas são situações bastante semelhantes àquelas caracterizadas nas citações de Charles Darwin e Bertrand Russell: os ignorantes confiantes em suas certezas; inteligentes inseguros e cheios de dúvidas.

Diferente dos ignorantes, o "impostor" parece não fazer uma imagem simplificada do mundo e de tudo o mais; ele reconhece que trabalhos, tarefas, conhecimentos, competências e perícia são coisas complexas demais para lidar com cega confiança nos procedimentos e resultados. Quando uma "vítima" da Síndrome do Impostor convive diretamente (numa organização, num departamento, em sala de aula, por exemplo) com uma "vítima" do Efeito Dunning-Kruger, agrava-se cada vez mais os dois casos, pois a pessoa confiante se impõe sobre a insegura e aumenta mais a sua empáfia; por sua vez, a outra pessoa pode se tornar ainda mais passiva, insegura, autodepreciativa e submissa, acarretando em quadros mais intensos de ansiedade e depressão.

\subsection{Um papel para o professor de filosofia}

Essa longa exposição teve o objetivo de sustentar a minha hipótese de que parte do "sofrimento psíquico" ou "adoecimento psíquico" dos estudantes poderia ser evitado ou, ao menos, contido e orientado se a comunidade acadêmica prestasse atenção aos sintomas e causas do "fenômeno do impostor" dentro do corpo discente (Herrmann, 2016). Decerto, isto não é trivial, haja vista que a responsabilidade dos professores é ensinar, engajar os alunos na pesquisa e prepará-los para atuar fora dos muros da universidade. Contudo, há as demandas e os pedidos de ajuda, não sendo razoável negligenciá-los ou deixar os estudantes à própria sorte. Isto é contraprodutivo para o ensino, para a pesquisa e a formação de cidadãos autônomos e saudáveis, bem como de profissionais íntegros e competentes. A vida psíquica e intelectual dos jovens recebe influência significativa do que se passa na universidade.

Apesar das demandas de meus estudantes, não tenho o preparo teórico, metodológico e técnico de um profissional da psicologia (como o leitor pôde perceber até aqui) para lidar com todos os seus problemas de ordem emocional e psíquica. Todavia, acredito que os conhecimentos e ferramentas adquiridas ao longo de minha própria carreira, principalmente nos últimos três anos como docente, sejam capazes de oferecer algum suporte. Tendo em vista que parte considerável dos quadros de sofrimento/adoecimento mental de alguns alunos aparecem no primeiro ano de graduação, quando constatam as diferenças entre as exigências intelectuais da academia e o tipo de ensino ofertado no ensino médio ${ }^{13}$, penso que a melhor maneira de os ajudar seja preparando-os para o estudo na universidade, contribuindo na transição entre meros números de matrículas para estudantes universitários. Impus isso como a minha responsabilidade enquanto um professor de filosofia em uma universidade sem um curso de Filosofia, pois tenho a vantagem de não precisar formar profissionais especializados para atuar em uma área específica.

Sendo assim, retomei minhas primeiras metas de ensino, as articulei com as pesquisas sobre noções de psicologia cognitiva e Universidade (próximas seções), dando origem à disciplina instrumental “Tópicos Especiais em Filosofia: O Estudo na Universidade". Esta foi elaborada com o propósito de dirimir as impressões que muitos estudantes alimentam de inadequação e de completa incapacidade para a vida acadêmica, sintomas do "fenômeno do impostor". A disciplina parte da premissa de que esses sentimentos - que geram angustia e insegurança - devem ser enfrentados logo no início do curso universitário e podem ser eliminados através do método do pensamento filosófico e do domínio de técnicas do trabalho acadêmico. Por isso, a proposta é introduzir os estudantes da UENF, especialmente àqueles matriculados nos cursos oferecidos pelo Centro de Ciências do Homem, a alguns elementos básicos de como estudar na universidade. Como se faz e para que servem os fichamentos, leituras analíticas, seminários e produção de ensaios analítico-críticos? Estas são as

13 Como deve ser do conhecimento do leitor, é elevada a quantidade de alunos que chegam à universidade com significativos déficits de aprendizado. Constata-se o problema naqueles que vêm tanto das instituições públicas de ensino médio, quanto das instituições privadas. 
perguntas básicas da disciplina; porém, a mesma não se limita à instrução sumária daquelas técnicas, pois a formação universitária exige mais do que isso.

Somadas à relevância de dominar as habilidades/ferramentas supracitadas está a compreensão dos objetivos educacionais relativos aos domínios cognitivos (lembrar, entender, analisar, aplicar, avaliar e criar) e do conhecimento (factual, conceitual, procedural e metacognitivo) ${ }^{14}$, dos elementos do pensamento crítico e de critérios intelectuais fundamentais (clareza, precisão, relevância, profundidade, abrangência, lógica, significância e honestidade) (PAul; Elder, 2006). Tendo em vista que a abordagem se dá à luz da Filosofia, espero que a familiaridade com esses conhecimentos teórico-conceituais e práticos leve à autorreflexão, ao autoconhecimento e às virtudes intelectuais (coragem intelectual, empatia, mente aberta, humildade e integridade intelectual, perseverança e autonomia intelectual). Isto, sim, promove os primeiros passos de uma vida acadêmica salutar, dando ao estudante propósito e confiança para aprender, avaliar e realizar suas obrigações discentes.

O fato de ser uma introdução a orientações gerais sobre o estudo na universidade não torna a disciplina restrita aos estudantes dos primeiros períodos, principalmente diante de casos de veteranos que seguem na graduação (e chegam a finalizá-la) com pouca ou nenhuma noção explícita de como ler, escrever e estudar ${ }^{15}$.

Ao final desse curso, o estudante deverá ser capaz de:

- Identificar, reproduzir e aplicar os objetivos educacionais da dimensão cognitiva;

- Identificar, reproduzir e aplicar os elementos do pensamento crítico;

- Identificar, reproduzir e aplicar padrões intelectuais considerados universais;

- Identificar, reproduzir e aplicar o hábito intelectual de compor e avaliar argumentos;

- Distinguir claramente entre premissas e conclusões;

- Clarificar proposições e justificá-las;

- Identificar falácias lógicas e vieses cognitivos;

- Entender, avaliar e realizar a produção de textos acadêmicos, tarefa que engloba:

- produção de esquema e de fichamentos (textual, temático e bibliográfico)

- realização de leitura analítica (textual, temática e interpretativa)

- problematizar o texto

- compor síntese pessoal

- Organizar, compor e apresentar seminários;

- Escrever um ensaio curto;

- Realizar exercício metacognitivo (autorreflexão e autoavaliação sobre seu desempenho no processo de aprendizado, emprego das habilidades, reconhecimento dos contextos de emprego, disciplina no reforço dos hábitos intelectuais, readaptação dos mesmos a um estilo pessoal e próprio).

Há alguma novidade nisso? Não. É apenas uma tentativa de retorno ao básico ${ }^{16}$, acreditando que a saída do problema está logo na entrada, no primeiro esforço para dirimir o déficit de aprendizado dos alunos de

14 Cf. Krathwohl, David R. "A revision of Bloom's Taxonomy: An overview” In Theory into Practice, v.41, n.4, 2002, p.212-225. Ferraz, Ana Paula. do C. M; Belhot, Renato V. "Taxonomia de Bloom: revisão teórica e apresentação das adequações do instrumento para definição de objetivos instrucionais” In Gestão e Produção, São Carlos, v. 17, n.2, p.421-431, 2010.

15 A disciplina está prevista para o primeiro semestre letivo de 2017, mas, em virtude das greves na UENF, não pôde ser iniciada até a data da submissão deste texto.

16 Tenho em mente algo semelhante às Artes Liberais em algumas universidades norte-americanas e europeias. A minha intenção, sinceramente, é resgatar o estudo do Trivium (Lógica, Gramática e Retórica) como disciplina obrigatória para todos os cursos nos dois primeiros anos da graduação. No entanto, a ideia seria considerada retrógrada e inútil em nossas universidades atualmente. 
ensino médio que chegam para estudar em curso de Ciência Humanas. Penso que seja um primeiro passo para experiências transformadoras nas universidades públicas nacionais hoje. Experiências de promoção de autonomia intelectual, promoção de segurança e autoconfiança, zelo e responsabilidade com aquilo que pensa, fala e escreve, com sua própria formação. Ademais, um aprendizado básico desse tipo pode ser capaz de instilar um senso de cooperação social através da busca pelas melhores formas de comunicar ideais, de escutar o outro, colaborando com as pessoas, com aqueles que são nossos "interlocutores" dentro de um sistema democrático. A universidade deve proporcionar as condições para que o sujeito entre em sala de aula com um ponto de vista e sinta-se à vontade para sair com outro, ou pelo menos mais esclarecido sobre suas crenças básicas e com dúvidas em relação às suas próprias convicções (ou às razões para ter tais convicções). Enfim, dentro de certas limitações profissionais (mais uma vez, não sou psicólogo), creio que assim podemos enfrentar as duas condições psicológicas e cognitivas aqui apresentadas: o efeito de superioridade ilusória e, principalmente, o fenômeno do impostor.

\section{Preservando o básico}

Por certo, meus objetivos pedagógicos pressupõem uma concepção de universidade, e procuro trabalhá-la em concomitância com os planos de disciplina expostos acima. Descrevo esse processo nesta seção.

\section{Passos para estudos sobre a Universidade}

No segundo semestre de 2014, ofereci a disciplina “Tópicos Especiais em Filosofia - Leituras sobre Universidade I”, cujo objetivo geral era introduzir os alunos à reflexão sobre a instituição em que se encontravam e o sentido da formação acadêmica, bem como o objetivo de familiarizá-los com a abordagens filosóficas, sociológicas e históricas sobre nosso objeto de estudo. À época (e isso se mantém), eu tinha a intenção de que a repercussão da disciplina gerasse a mobilização pelo estabelecimento de um programa permanente de estudos sobre Universidade. Eu parti do pressuposto de que a ausência de discussão séria sobre o assunto era provocada pela alienação de professores, estudantes e técnicos administrativos, seja por falta de interesse, falta de oportunidade ou por pura obtusidade. Talvez, o engajamento em questões sobre a Universidade seja considerado inútil, um enfado, perda de tempo, bem como algo que atrasaria a busca e o rápido acesso dos alunos ao diploma superior e ao mercado de trabalho, atrapalharia a produção de dissertações, teses e artigos científicos. Sendo esse o caso, é admissível afirmar que a perspectiva mercadológica - imediatista, reducionista e instrumentalista - impere, completa e inapelavelmente, na Universidade.

A ideia da disciplina e do programa almejado era se contrapor a tal conjuntura, abrindo uma oportunidade para problematizá-la. A premissa básica dos meus planos é a de que todo membro da comunidade acadêmica deve entender as circunstâncias da instituição da qual faz parte, de modo a ser capaz de refletir, posicionar-se, engajar-se, criticar e, no melhor dos casos, fazer parte dos processos de tomada de decisão sobre a política do conhecimento. Afinal, os conhecimentos preservados, produzidos e distribuídos pelas universidades têm um papel fundamental nas decisões sobre os modos como vivemos e nos organizamos em sociedade.

Realizei a segunda edição da disciplina no segundo semestre letivo de 2015. Me chamou a atenção o misto de surpresa e frustração dos alunos ao aprenderem mais sobre a Universidade, enquanto conceito e instituição, modelos de universidades e a história da universidade brasileira. Eles entendiam as raízes do caráter disfuncional e confuso de nossas instituições de ensino superior. A palavra "crise" era onipresente em sala de aula. No mesmo ano de 2015, comecei a orientação de uma pesquisa de iniciação científica tratando da Universidade. Seu título (pretensioso) foi "O que todo estudante universitário brasileiro precisa saber sobre Universidade? - primeiro passo: entendo a "Crise da Universidade". O segundo passo foi investigar a percepção dos estudantes da UENF sobre a $\mathrm{crise}^{17}$. Em resumo, tivemos como resultado o seguinte:

17 O projeto que deu origem a essa pesquisa de iniciação científica teve o apoio da Faperj através de verba concedida através de Auxílio Instalação. Sou grato à minha orientanda Laira Thamys de Araújo Silva, estudante do curso de Administração Pública (LGPP/CCH), por colaborar nesta pesquisa. 
constatação da perda de nexo entre Universidade, Cultura (ausência de um "Projeto de Nação") e Formação (Bildung); gestões universitárias incompetentes em virtude da incompreensão sobre o que seja Universidade; desinteresse dos professores em relação ao ensino e à formação dos graduandos em virtude da prioridade dada à pesquisa, à pós-graduação e ao lucro proveniente de convênios com empresas privadas (relações escusas entre Universidade-Indústria-Mercado); desvalorização das Humanidades (Filosofia, Ciências Sociais, Letras e Artes); foco equivocado sobre a mera profissionalização, levando à perda do sentido da formação universitária integral, os egressos se apresentam a sociedade como prática e tecnicamente competentes, porém acríticos e pouco reflexivos. De um modo geral, portanto, observa-se conflitos entre modelos diferentes de universidade dentro de uma mesma instituição e, em especial, falta de consenso sobre objetivos e valores da instituição. A maioria dos estudantes (os matriculados na disciplina e os entrevistados) acreditavam que a "crise da universidade" se resumia à problemas econômicos (falta de investimento público), embora os mesmos tivessem apontado outros itens dos resultados supracitados.

\subsection{Tentando orientar os perplekos}

Meu desejo era (e ainda é) proporcionar aos estudantes a experiência transformadora pelo qual passei dez anos antes de eles me encontrarem. Em 2004, primeiro ano de meu curso de mestrado em Filosofia, pude acompanhar uma disciplina sobre o modelo humboldtiano de universidade moderna e a formação pela ciência. Desde então, carrego esse modelo como um parâmetro que vale a pena ser respeitado e amplamente difundido. Mesmo que de forma bastante modesta, consegui realizar isso através daqueles cursos, algumas palestras e conversas informais com os estudantes. Estes entenderam que, a despeito do mantra governamental, empresarial e midiático, há mais na Universidade e na formação acadêmica do que a relação com inovação tecnológica e mercado de trabalho. Há algo a se conservar dos modelos clássicos de universidade; no entanto, fazer isso não é trivial.

As constatações de minha orientanda em sua pesquisa e a dos frequentadores da "Leituras sobre Universidade" estão em consonância com a de estudiosos como Altair Fávero:

Desse processo de expansão, ampliação das funções e popularização da universidade deriva uma contradição entre algumas de suas funções. A função de investigação, por exemplo, passou a colidir frequentemente com a do ensino, pois o processo de criação e produção de conhecimento exige uma dinâmica própria (mobilização de recursos financeiros, qualificação de recursos humanos, infraestrutura, etc) que não se coaduna com a dinâmica do ensino (transmissão de saberes historicamente elaborados). Da mesma forma, na maioria das vezes, não são compatíveis os interesses científicos dos pesquisadores e os da economia, ou os objetivos da educação geral e os da formação profissional (educação especializada) (FÁvero, 2010, p. 82-83).

Diante desse quadro complexo, os alunos, em especial aqueles das Ciências Humanas, veem explicitadas as contradições e a origem de muitos dos problemas com os quais esbarram cotidianamente. Ademais, percebem que não é tão natural, fácil e trivial exigir que a Universidade "vá a sociedade", "atenda suas demandas", " se relacione com a sociedade". A mesma tensão se dá em relação ao Estado. O que querem de nós se resumirá à utilidade e mobilidade social, à produtividade econômica, à "produção" de graduados e pós-graduados empreendedores e "empregáveis"?

Contradições e tensões geram momento de crise, pois decisões precisam ser tomadas, escolhas devem ser feitas, de modo que um (ou mais) dos elementos em conflito seja eliminado do jogo. Porém, esse "momento" se estende, tornando-se uma condição histórica e existencial. Em termos de universidade brasileira, já estamos bastante acostumados com esse prolongado estado de crise, ou de crises. A palavra "crise" também designa a elaboração de um diagnóstico sobre o presente. O sociólogo português Boaventura de Sousa Santos apresentou um desses diagnósticos e uma das mais claras classificações da crise da universidade, ou melhor, a "tripla crise": hegemonia, legitimidade e institucional. 
Crise de Hegemonia: "A universidade sofre uma crise de hegemonia na medida em que a sua incapacidade para desempenhar cabalmente funções contraditórias leva os grupos sociais atingidos pelo seu déficit funcional ou o Estado em nome deles a procurar meios alternativos de atingir seus objetivos" (SANTOs, 2013, p. 375-6). Crise de Legitimidade: "Contradição entre hierarquização e democracia. A universidade (também) sofre essa crise na medida em que se torna socialmente visível a falência dos objetivos coletivamente assumidos (Idem). Crise Institucional:

Contradição entre autonomia institucional e produtividade social. Há uma crise institucional sempre que uma dada condição social estável e autossustentada deixa de poder garantir os pressupostos que asseguram a sua reprodução A universidade sofre essa crise na medida em que sua especificidade organizativa é posta em causa e se lhe pretende impor modelos organizativos vigentes noutras instituições tidas por mais eficientes" (Idem) ${ }^{18}$.

Cabe algumas palavras a mais apenas para ilustrar a crise de hegemonia. A funções contraditórias mencionadas acima expressam-se assim: Alta Cultura x Cultura Popular - "Contradição entre produção de alta cultura incumbida de formar as elites desde os seus primórdios e a produção de padrões culturais médios responsáveis por produzir conhecimentos úteis para modificações sociais e para a formação da força de trabalho necessária ao desenvolvimento industrial" (SANTos, 2013, 378-402). Educação x Trabalho (formação humanística x formação profissional):

no que se refere à educação humanística, cabia à universidade transmitir a alta cultura, formar o caráter, possibilitar a aculturação e socialização na direção da sociedade etc. No que diz respeito à formação profissional, cabia à universidade a tarefa de ensinar conhecimentos utilitários, repassar aptidões técnicas especializadas, responder aos desafios do desenvolvimento tecnológico no espaço de produção etc.

\section{$[\ldots]$}

Pela rigidez institucional da própria universidade não há sintonia entre as exigências do mercado e a maneira como é estruturada a formação do profissional que ela está formando. É por isso que muitas empresas, por considerarem que a formação universitária é lenta e dissociada dos interesses diretos das demandas do mercado, criam seus próprios cursos de formação profissional. (FÁvero, 2010, p.86)

Finalmente, relação Teoria x Prática: "contradição entre reinvindicação da autonomia na definição de valores e objetivos e a submissão crescente a critérios de eficácia e de produtividade de origem e natureza empresariais" (Santos, 2013, p.378-402). Temos a tensão entre ciência básica e ciência aplicada dentro das universidades públicas.

Isto foi o bastante para se ter alguma noção significativa sobre os fatores responsáveis por caracterizar a "crise de identidade" da Universidade atualmente. A pergunta mais comum em sala de aula era a respeito das possibilidades de conciliação entre as partes em conflito. Esse tipo de questionamento conduz à consideração de modelos universitários. Qual deles seria uma alternativa ou proporcionaria alguma condição para que as decisões diante da "crise de identidade" não levassem à perda de valores e práticas fundamentais?

Simon Schwartzman apresenta esses modelos através de uma adaptação da tipologia das instituições universitárias elaborada pelo cientista político norueguês Johan Peder Olsen ${ }^{19}$. Abaixo, segue um esquema dessa tipologia baseado na adaptação do sociólogo brasileiro (Schwartzman, 2014, pp.38-41).

18 Para uma apreciação completa da tripla crise ver Santos, 2013, pp.371-428.

19 Olsen, Johan P. “The institutional dynamics of the European university” In: MaAsEN, Peter \& OlsEN, Johan P. (eds.) University Dynamics and European Integration. Dordrecht, Springer, 2007, pp. 25-54. Cf. MiguEL, L.R., 2017, pp. 168-169. 
No "Modelo Clássico" ("universidade como comunidade acadêmica autogerida"), há consenso entre professores, funcionários e alunos sobre os valores e objetivos da instituição universitária; possui recurso próprios ou financiamento estável e garantido, sua lógica interna obedece a princípios de mérito, racionalidade, liberdade de pesquisa, e é fortemente colegiada; sua autonomia é justificada por ser a universidade governada pelos mais competentes; modelo estável, mas depende de se renovar constantemente, sendo este seu maior desafio. Corre risco de enrijecer-se, de se fechar para o mundo externo e perder posição de liderança intelectual, reconhecimento público e apoio da sociedade.

Temos a "Universidade Operacional”20 ("universidade como instrumento de agendas políticas nacionais"), na qual existe consenso sobre valores e objetivos, mas precisam responder a agenda política estabelecida pelo governo; recebe recursos públicos, mas estabelece relações com a iniciativa privada; administração forte, gerencial, responsável por garantir cumprimento de metas e expectativas governamentais, uso eficiente dos recursos públicos, emprega sistemas de avaliação; sua autonomia depende, sobretudo, da eficiência de sua direção em atender expectativas (do Estado e da sociedade); mudança de governos ou alterações nas políticas públicas podem prejudicar seu funcionamento; devem ser capazes de mudar e se adaptar às novas expectativas.

A "Universidade Pública Latino-Americana/Brasileira", segundo Schwartzman, apresenta pouco consenso entre professores, funcionários e alunos a respeito de seus objetivos e valores; diferentes setores e grupos se organizam para fazer valer interesses e pontos de vista; existem diferenças profundas, especialmente entre professores, entre a qual elemento dar mais peso e se dirigir sua dedicação: formação mais acadêmica ou Dedicação ao ensino, atenção áreas Básicas ou às áreas Tecnológicas; à pesquisa básica ou à Pesquisa Aplicada? Os recursos são predominantemente públicos; a lógica interna funciona como uma democracia representativa: autoridades são eleitas pela maioria ou por coligação, a governança se dá por concessões ou acomodação de interesses de diversos setores, a autoridade legitimada por processo político de sua eleição, não pela competência gerencial. Em virtude de seus conflitos internos e questões com o Estado, esse tipo de universidade é voltado para seus próprios problemas do dia a dia. Demonstra dificuldades de entender as transformações e em aprender a lidar com elas; as mudanças dependem, em geral, das variações que possam existir na força relativa de seus diferentes setores.

Por fim, o modelo que considero mais inútil, a "Universidade Empresarial” ("universidade como empresa de serviço em mercados competitivos"): não existe consenso a respeito de objetivos e valores; os recursos são, predominantemente, privados, embora programas dos últimos governos tenham injetado dinheiro nessas instituições; a lógica Interna segue o modelo de empresas privadas; professores são funcionários empregados; alunos são clientes. Não existe autonomia; a liderança é forte, indicada por proprietários, acionistas e outros que definem objetivos da instituição, sua legitimidade depende de capacidade de captar recursos. São sensíveis às mudanças no mercado, mas buscam se adaptar, identificar seus nichos de oportunidade e, obviamente, maximizar seus lucros.

Qualquer sociedade democrática deve decidir, com conhecimento de causa e clareza, o(s) modelo(s) que considera pertinente(s). Contudo, enfatizo a atenção à possibilidade de fazer coexistirem os diversos valores, objetivos e fundamentos que tomo aqui como sendo "originários" da ideia de Universidade. Embora a "crise de identidade" se mantenha, pelo menos os estudantes terão alguma oportunidade de usufruir sua experiência universitária como algo transformador.

\subsection{Um conservadorismo razoável}

Como foi visto acima, entender a Universidade é muito mais complicado do que parece, é um terreno delicado de se transitar. Entretanto, independente dos ruídos, da cacofonia, da "esquizofrenia" dos discursos populares atuais sobre a serventia das universidades e das pressões empresariais em nome da "cultura inovacionista" (Oliveira, 2015), é mister buscar brechas no próprio cotidiano acadêmico para preservar e cultivar determinados objetivos e valores originários da ideia de Universidade, de um modelo o mais

20 Essa expressão não é de Schwartzman (2014). É empregada por Marilena Chauí em seus artigos em CHAUí, M. Escritos sobre a universidade. São Paulo: Editora UNESP, 2001. 
próximo possível daquele referido acima como "clássico". Seria uma tentativa de propagar e "simular" entre os estudantes a experiência universitária que encontrada no já referido modelo humboldtiano. Embora este nunca tenha sido plenamente realizado ${ }^{21}$, penso que devemos persistir, e podemos nos inspirar nas palavras de Darcy Ribeiro (1922-1997) ao encerrar o preâmbulo ao Plano Orientador da UENF: "Dos planos que fiz, nenhum se cumpriu como fora pensado. Mas sua existência deu coerência e diretriz à vida universitária que prefigurou" (RIBEIRO, 1993, p. 8).

À guisa de esclarecimento, apresento um esquema simples e econômico de quatro características do modelo universitário moderno, que o polímata alemão Wilhelm von Humboldt (1767-1835) estabeleceu para a Universidade de Berlim, fundada em 1810. A saber: educação de nível mais avançado do que o Ensino Médio, sendo que por "educação" entende-se algo mais do que "treinamento profissional"; promover ensino e pesquisas avançados, os quais não são totalmente ditados pela necessidade de resolver problemas práticos imediatos; as atividades de ensino e pesquisa são desenvolvidas através de mais de uma disciplina ou conjunto muito restrito de disciplinas; goza de autonomia institucional para determinar suas atividades intelectuais (isto é, não intervenção estatal e da sociedade sobre o que pesquisar e ensinar) (Collinı, 2012, p.7. A tradução é minha). Observa-se que estão expressos acima: o ideal de Formação Integral do indivíduo (Bildung); a unidade entre ensino-pesquisa; o caráter não instrumental dos conteúdos e resultados de ambos; a interdisciplinaridade e a cooperação; a autonomia da ciência e a autonomia administrativa.

Convém enfatizar que a formação entendida como Bildung não se limita à instrução profissional, assim como a formação através da ciência não se esgota nas ciências empíricas, diz respeito "ao cultivo do homem como um todo" (BARbosa; VideIRA, 2005, p.34). Talvez, isto não faça mais sentido atualmente; entretanto, todos os meus planos de ensino e pesquisa descritos até aqui são dedicados a revigorar minimamente essa ideia, mesmo que seja durante um ou dois anos na experiência acadêmica dos estudantes. As demandas do século XXI (assim como as do industrialismo do século XIX) acabaram por se tornar obstáculos ao cultivo da Bildung. Contudo, acredito ainda ser possível exortá-lo na vida de um número significativo de pessoas da comunidade acadêmica.

Para tanto, é preciso haver um senso razoável de conservadorismo universitário. Me refiro à noção de "conservadorismo educacional" mencionado pela filósofa alemã Hannah Arendt (1906-1975) em "A crise da educação" (1957)22. Arendt se referia à educação de crianças, não à de jovens adultos; porém, o importante é a ideia do conservadorismo na educação:

Evitemos os mal-entendido: penso que o conservadorismo, tomado enquanto conservação, faz parte da essência mesma da atividade educativa cuja tarefa é sempre acarinhar e proteger alguma coisa - a criança contra o mundo, o mundo contra a criança, o novo contra o antigo, $\mathrm{o}$ antigo contra o novo. A própria responsabilidade alargada pelo mundo que a educação assume implica, como é óbvio, uma atitude conservadora. Mas, isto só é válido para o domínio da educação, ou melhor, para relações entre crescidos e crianças e, de modo algum para o domínio político, onde agimos sempre entre e com adultos ou iguais (ARENDT, 1957, p.12).

21 Cf. Barbosa; Videira, 2005, p.35. "Desde que foi criado, em 1810, com a fundação da Universidade de Berlim, o modelo de Humboldt não permaneceu o mesmo. As transformações no plano científico foram acompanhadas de outras no plano institucional. Se, por um lado, a dissolução do idealismo especulativo, a introdução de novo métodos (laboratoriais, filológico, matemáticos, entre outros) e o surgimento de novas disciplinas e tecnologias tronaram a universidade mais complexa, por outro resultaram no início do processo de sua fragmentação. O modelo defendido por Humboldt e seus colegas se desfigurou, mas se mostrou suficientemente flexível para sustentar o crescimento de uma de suas variações, favorável à inserção plena da ciência e da técnica na 'ordem do ensino universitário', sem prescindir do respeito à liberdade e à autonomia"

22 Sou grato à estudante do curso de Licenciatura em Pedagogia (LEEL/CCH-UENF) Clara Mara Gonçalves Chaves por me apresentar esse artigo de Hannah Arendt. 
À luz do que foi apresentado na seção 3 deste texto, o leitor pode perceber que levo a sério a tarefa de "acarinhar" e "proteger contra o mundo" os jovens adultos que chegam até mim, especialmente porque ingressam no ensino superior despreparados em quase todos os aspectos, desesperados com as incertezas do futuro, se arrastando num presente lastimável e sem qualquer passado significativo.

Também emprego essa concepção de conservadorismo para sustentar, como se pode notar, o esforço de se preservar e cultivar determinados valores e objetivos em meio às várias faces da crise de identidade da universidade. Porque, como é bem sabido, uma crise também se instaura nas relações do "novo contra o antigo, o antigo contra o novo", bem como, vale destacar, do "inútil contra o útil", da "utilidade contra a inutilidade". Principalmente, quando são suprimidos da arena de discussões os recursos para estabelecer a coexistência entre o "velho" e o "novo", assim como são deturpados os critérios para reconhecer o que é útil ou inútil.

Segundo Pierre Hadot, citado como epígrafe da introdução do livro de Nuccio Ordine, "A utilidade do inútil: um manifesto" (2016), a "tarefa da filosofia é mesmo a de revelar aos homens a utilidade do inútil". Parafraseando Ordine, meu propósito é acarinhar, proteger e conservar a paradoxal "utilidade do inútil":

A utilidade paradoxal à qual me refiro não é aquela em nome da qual os saberes humanísticos e, de modo mais geral, todos os saberes que não trazem lucro são considerados inúteis. Numa acepção muito mais universal, coloco no centro das minhas reflexões a ideia da utilidade daqueles saberes cujo valor essencial está completamente desvinculado de qualquer fim utilitarista. Há saberes que têm um fim em si mesmo e que - exatamente graças à sua natureza gratuita e livre de interesses, distante de qualquer vínculo prático e comercial - podem desempenhar um papel fundamental no cultivo do espírito e no crescimento civil e cultural da humanidade. Nesse sentido, considero útil tudo o que nos ajuda a nos tornarmos melhores (ORDINE, 2016. Grifo do autor)

Este excerto expressa a letra e o espírito da minha concepção básica de como a universidade deve ser útil para a sociedade e como locus de experiências transformadoras.

\subsection{Proteger do quê? - Alguns exemplos}

Voltemos aos lugares-comuns. Um dos mais recorrentes aparece em congressos e palestras no âmbito acadêmico com títulos como: "A universidade frente aos desafios da Inovação Tecnológica". Posiciono-me contra uma das possíveis interpretações de um título desses, que seria algo assim: "as universidades (independentemente de seu modelo, ou dos modelos que tentam abraçar) precisam se adequar e se adaptar cada vez mais às Ciências Aplicadas e à Inovação Tecnológica ${ }^{23}$, a fim de atender as demandas da sociedade de mercado". Sou mortalmente contra, entre outras coisas, porque penso que as universidades públicas não devam continuar carregando o ônus da perda de sua autonomia, tampouco de seus valores e objetivos fundamentais para atender freneticamente aos critérios e às pressões por eficácia e produtividade de natureza empresarial, mesmo em face de "chantagens" como "se a Universidade não incorporar plena e absolutamente a perspectiva da administração empresarial e do mercado, ela não conseguirá cumprir sua responsabilidade social”.

Convém esclarecer que não sou contra a ciência nem a tecnologia (por vontade e profissão, as investigo e critico), mas desconfio da supervalorização imediata daquilo que vem dentro do pacote com o rótulo de "Inovação". Por isso, minhas impressões a respeito desse assunto não se baseiam no ponto de vista confiante de quem convive diretamente, exalta e dá prioridade aos papéis e lugares da Inovação Tecnológica, nem aos seus meios e fins de ordem mercadológica na Universidade.

Lanço mão de outro lugar-comum: parece que as universidades foram vítimas de um sequestro. O problema é que se acostumaram com a situação; há tempos, sofrem da Síndrome de Estocolmo. Mas não apenas

23 Segundo Renato Pedrosa (2014, p. 223, 7n): “Uma forma 'economicista' de colocar os dois lados do processo [pesquisa e inovação/desenvolvimento] é: a pesquisa consiste em transformar fundos (dinheiro) em conhecimento, enquanto a inovação seria a atividade que transforma conhecimento em dinheiro (fundos). A comercialização, incluindo a criação de novos mercados, faz parte do processo de inovação". 
simpatizaram e abraçaram a causa de seus "raptores", como também desejam ser como eles. Consequência: as universidades vêm deixando de ser instituições sociais para se tornarem empresas diretamente vinculadas ao mercado (Doria et al, 1998; CHAúí, 2001). Nas palavras do editor executivo para a área de Humanidades da Harvard University Press Lindsay Waters: "como as pessoas consideram o mercado livre a referência fundamental, acabamos adotando a mentalidade "tamanho único" e comprovamos seu efeito desestabilizador sobre a universidade (Waters, 2006, p. 16).

Sem dúvida isso não é novidade para muita gente. Talvez, não seja considerado um problema para a maioria dos estudantes e dos pais destes, talvez tenha sido a melhor coisa que aconteceu para salvar a ciência e a universidade no Brasil. O que tem de mais em unir de modo imediato formação e labor científico com o tipo particular de produção capitalista? O país precisa crescer, desenvolver-se, "fazer dinheiro". Até Darcy Ribeiro, à sua maneira, concordava com isso: a universidade como instrumento de saída do subdesenvolvimento, essa conversa de "o conhecimento por si mesmo" é para filósofo elitista que não passa fome. Só um tolo poderia acreditar que é uma péssima ideia amestrar o setor universitário através de avaliações baseadas na lógica da produção mercantil. Essas opiniões (postas aqui de forma generalista) fazem parte das preocupações de uma sociedade democrática. Ainda assim, precisamos de um conservadorismo universitário razoável, a fim de preservar o sentido da Universidade. Parafraseando Waters mais uma vez, o dinheiro reestruturou a academia à sua própria imagem, mas "o dinheiro é um instrumento grosseiro" (Waters, 2006, p.17).

Minha paranoia intelectual me leva a suspeitar que os desastres encontrados na biografia da universidade brasileira como um todo parecem ser premeditados, pois a crise, ou as crises, precisam ser mantidas ${ }^{24}$. Afinal, crises também são momentos de oportunidade, especialmente para os que se beneficiam com o enfraquecimento e a aniquilação daquilo que não é considerado conveniente (útil) a seus planos. É sabido que uma crise pode ser instaurada deliberadamente. Isso se dá mediante o encobrimento das condições que nos permitiriam encontrar possibilidades de busca e avaliação de novas e melhores soluções, opções ou alternativas para tomar decisões sobre os caminhos que precisamos seguir. Temo que o "inovacionismo" também se apresente como um modo de encobrimento de sentidos, valores e problemas, bem como de alternativas; logo, é parte do processo de manutenção da "crise da Universidade".

Admito que as universidades aproveitem a "onda da inovação", mas subvertendo-a, isto é, elegendo a si mesma como prioridade. A grande inovação seria tomar um distanciamento crítico em relação à Inovação Tecnológica (doravante, IT). Aos olhos contemporâneos, a IT justificaria a existência e, lamentavelmente, daria identidade e sentido à Universidade, de modo que o grande desafio desta frente ao "inovacionismo" seria voltar-se para si mesma, recuar e reagrupar, para reformar-se, restaurar-se, sem a intervenção tão direta dos fatores que já comprometeram sua autonomia. Portanto, "inovar" seria refletirmos sobre nós mesmos enquanto "comunidade acadêmica", além, claro, de entender e valorizar a formação de nossos estudantes para além dos laços com a IT, com o mercado, o modelo de administração empresarial e suas medições, seus controles, as competições, os índices e rankings de eficiência e com o "produtivismo tóxico".

Diante dessas colocações, pode-se perguntar: como as universidades atrairão recursos se não usar o rótulo "IT"? Não seria um erro estratégico, um ato insensato ou um "tiro no pé" se formos de encontro aos fatores que, supostamente, "agregam valor" (essa expressão infame da semântica do Mercado) à Universidade enquanto uma marca? Quem irá pagar a conta das universidades nesse cenário de precariedade e miséria econômica e política? Quem vai valorizá-la se não houver o apoio da indústria e do mercado? O que fazer quando o próprio Estado interfere na autonomia e, pior, se coloca como um dos braços de destruição da educação pública de qualidade?! Qual é a saída?!

Estas são perguntas a se considerar, e, sinceramente, não tenho respostas satisfatórias e razoáveis no momento. Não obstante, penso ser primordial entender o que está em jogo nos problemas. Para tanto, seria mais conveniente perguntar: "qual é a entrada?"; pois é difícil tentar resolver qualquer problema sem saber

24 Lembremo-nos da célebre e sempre repetida declaração de Darcy Ribeiro: "A crise da educação no Brasil não é uma crise, é um projeto" (palestra "Sobre o óbvio", apresentada em congresso da Sociedade Brasileira para o Progresso da Ciência em 1977). 
do que se está tratando ou tendo apenas ruídos na comunicação, ambiguidades, omissões, manipulações, vieses e falácias. Uma das "entradas de emergência" são as análises e os estudos conceituais que mobilizam materiais, métodos e atitudes questionadoras e críticas tanto da Filosofia e das Humanidades, quanto das Ciências Naturais.

Nós vivemos a partir de conceitos, como escreveu o filósofo e linguista búlgaro Tzvetan Todorov: "Para nos comportarmos como seres responsáveis, precisamos de um plano conceitual que possa fundamentar não somente nossos discursos, o que é fácil, mas também nossos atos" (2008, p.9). Ou seja, conceitos baseiam e orientam as práticas e as maneiras como pensamos e nos comportamos, especialmente ao tentarmos construir nossa vida em comum. Isso não é algo banal e inútil! À luz dessas ideias, repito, penso que quaisquer planos de reforma universitária serão insatisfatórios enquanto carecermos de maior compreensão e crítica conceitual sobre o que seja "Universidade", "Formação", "Ciência", "Crise", "Tecnologia" e "Inovação". Penso que para evitar bases instáveis em qualquer empreendimento, não há nada mais prático do que uma boa teoria, como disse o meu primeiro professor de filosofia. Contudo, uma vez que instituições não são imunes à incompetência, à má-vontade e ao mau-caratismo inerentes à natureza humana, é provável que os planos de reformas continuem desastrosos a despeito de esclarecimentos teórico-conceituais razoáveis.

Não seria útil, por exemplo, se a Universidade assumisse o desafio de repensar e reaprender o que "Autonomia" significa e por que é importante para a realização de suas missões fundamentais? O mesmo reaprendizado conceitual também vale, insisto, para o significado de "Formação Universitária", que não se limita à formação profissional, à formação para o mercado de trabalho. Estamos falando também de educação humanística, de formação que entrelaça intelecto, caráter e cultura, atitudes crítica e reflexiva, integrando Humanidades, Ciências e Tecnologia. Tendo a pensar que de pouco adianta a pessoa sair da universidade sendo científica e tecnicamente competente, mas culturalmente oca, alheia a tudo o que não diga respeito à sua especialização, um mercenário com discurso corporativo e postura de bom moço.

\section{Notas de esperança em uma palestra}

Em 21 de agosto de 2017, o ex-reitor da Universidade de Lisboa, Prof. António Nóvoa, proferiu uma palestra na ocasião das comemorações pelos 24 anos da Universidade Estadual do Norte Fluminense Darcy Ribeiro. A despeito das reconhecidas diferenças políticas e culturais relativas à educação universitária entre Portugal e o Brasil, as palavras do Prof. Nóvoa foram motivadoras, especialmente por ir ao encontro dos meus esforços e oferecer uma visão mais equilibrada do que a minha. Aliás, "equilíbrio" é uma palavra-chave nas ideias dele. No que se segue, tento compor um resumo da palestra.

Nóvoa apresentou sua teoria dos " $4 \mathrm{E}$ " para desenvolver suas ideias sobre como estabelecer algum equilíbrio entre os valores e objetivos fundamentais da Universidade e os critérios e demandas extrínsecas a ela. Desnecessário dizer que ele argumentava a favor de tal reequilíbrio. A teoria dos "4E" designa os fatores/ conceitos que vêm desestabilizando e provocando as crises da Universidade: Empregabilidade, Empresarialização, Excelência e Empreendedorismo. Segundo Nóvoa, não há como as universidades se livrarem desses "Es" sem perder a capacidade de fazerem algum sentido no século XXI e além. A globalização, a sociedade pós-industrial, o "mundo digital" têm esses "Es" como parte constitutiva, e as universidades não devem nem podem negar isso, pois, afinal, não estão alheias às transformações e ao tempo. O problema está na postura passiva e submissa diante de tudo isso (lembre-se da Síndrome de Estocolmo), e é aí que entra a valorização da autonomia para buscar o equilíbrio (não exatamente um sinônimo para "harmonia") entre universidades públicas e aqueles critérios externos. As demandas externas podem vir a nós, mas deve haver negociação entre partes que se olham frontalmente, de igual para igual.

A empregabilidade é um critério/fator bastante delicado, pois toca na questão da utilidade da universidade, mais precisamente na utilidade de determinadas disciplinas. Todo professor, pesquisador e estudante da área de Ciências Humanas, Filosofia e Artes entende muito bem esse caso, já que a sociedade demanda modelos de universidade que valorizem as disciplinas consideradas "úteis". Há o crescimento da convicção 
de que o Estado deveria bancar apenas as disciplinas "úteis", as quais, nas palavras de Nóvoa, fazem parte do acrônimo STEM: Science, Technology, Engineering and Math (Ciência, Tecnologia, Engenharia e Matemática). Se estivermos falando, de fato, de universidades públicas, temos que afirmar a perda de seu sentido diante de uma demanda desse tipo. O reducionismo e a especialização irão dominar, e continuará sendo reproduzido o velho conflito entre as "duas culturas" - Humanidades x Ciências (e engenharias) ${ }^{25}$. Sem uma formação ampla, recrudescerá a briga entre "cultos ignorantes" (pessoas "de Humanas" que nada sabem sobre ciências) contra "instruídos incultos" (cientistas e engenheiros cultural, política e socialmente incompetentes).

A empresarialização é um fenômeno bastante conhecido no Brasil desde o crescimento dos investimentos no ensino superior privado, especialmente a partir da década de 1970 (SAmpaio, 2014). Nesse sentido, o termo é sinônimo de "privatização" ou "mercantilização" da educação. Mas não é apenas sobre isso que se trata aquele conceito empregado por Nóvoa. A empresarialização da instituição universitária se dá de forma mais insidiosa quando o próprio Estado se baseia na lenda da empresa como modelo de organização, adotando prontamente modelos empresariais de gestão (lembre-se dos modelos "operacional" e "empresarial" descritos anteriormente). Os interesses econômicos ficam cada vez mais fortes na universidade e o que acaba prevalecendo é o seu valor econômico. Desnecessário dizer que a invasão dos "lobos" empresariais ameaça diretamente a autonomia acadêmica e demais valores fundamanetais (HALFFMAN; RADDER, 2017).

Em terceiro lugar, temos um termo que, outrora, fazia parte da semântica das virtudes, mas que, atualmente, faz parte da linguagem empresarial: Excelência. Ligada as noções de eficiência, eficácia e produtividade, a excelência acadêmica se encontra menos na qualidade das produções do que na quantidade das mesmas. A excelência é avaliada, em geral, mediante um produto chamado paper ou "artigo científico". Para se ter um paper, é necessário realizar pesquisa. A realização de pesquisas é uma das missões da universidade enquanto produtora e distribuidora de conhecimento, mas o problema está no descompasso entre a atividade de pesquisa e as atividades de ensino e extensão, outras duas missões da universidade. O critério de excelência, à luz da visão do Mercado, privilegia a pesquisa em detrimento do ensino. São as pesquisas e os papers que geram lucros e passaram a "sustentar" as universidades. Para justificar sua existência, os professores-pesquisadores universitários precisam "pontuar" e concorrer entre si, além de deixarem de lado o ensino. Seguindo esse raciocínio, a corrida pela excelência instaurou um tipo de competição acadêmica que abala um de seus critérios originários, a cooperação. Estamos diante, então, do insuportável (e, em geral, anódino) produtivismo e daquilo que Nóvoa chamou de "capitalismo acadêmico". Nesse cenário de "Jogos Vorazes", o ensino é deixado de lado, é secundário, um "obstáculo" para a pesquisa, e não parte complementar desta (preparar planos de curso e de aulas, e estar em sala de aula ensinando são atividades que tomam muito tempo, mas "tempo é dinheiro", certo?). A "Excelência" tornou-se um vício acadêmico, pondo em cheque a unidade entre ensino e pesquisa e a cooperação na academia.

Por último, mas não menos ameaçador, temos o Empreendedorismo. Assim como a excelência, não é, originalmente, um valor deletério; no entanto, dentro do novo modo de produção do conhecimento nas universidades ${ }^{26}$, tornou-se um comportamento subjugado ao capitalismo acadêmico. Ser empreendedor é conseguir transformar conhecimento produzido em universidades públicas em produtos com valor comercial. Há, assim, a valorização das tecnologias e iniciativas "comerciáveis", gerando patentes, commodities, start ups e spin-offs. Despreza-se a ciência básica em nome da ciência aplicada. Para Nóvoa, o problema não está nessas práticas, nem na geração de coisas para o comércio. Isto até dá retornos positivos à universidade. Ademais, é parte da tarefa das universidades formarem pessoas com espírito empreendedor, dotá-las de conhecimento e técnicas para empreender e estimular isso. Todavia, o perigo está nas políticas educacionais construídas a partir apenas daquela noção estreita de empreendedorismo.

Ao final, António Nóvoa apresenta os contrapontos aos aspectos negativos do "4E”. Em primeiro lugar, a revalorização da educação ampla: científica e cultural. Retomada da formação geral, uma concepção que EDUSP, 2015.

26 Cf. Dos Reis; Videira, 2013. 
remonta ao espírito das primeiras universidades europeias. Uma iniciativa para isso é a Licenciatura em Estudos Gerais, inaugurada na Universidade de Lisboa, em 2011, "segundo o espírito original da fundação daquela universidade no século XIII" (Ribeiro, 2014). "Estudos Gerais" retoma o sentido dos Studium Generale das universidades medievais. Segundo António Feijó, um dos idealizadores do curso e ex-vice-reitor da Universidade de Lisboa (quando Nóvoa era reitor), Estudos Gerais não ensina profissões: é um curso que "cultiva todos os saberes e os alunos podem ter acesso a todos eles" (idem). Essa iniciativa é um contraponto ao critério da empregabilidade. Ainda segundo Feijó:

As pessoas estão na universidade não para arranjar emprego, mas para serem educadas, para terem uma educação formal, no sentido do conhecimento, do saber, estruturado e organizado, de alta exigência e que as equipa, lhes dá a capacidade de serem autônomas, conhecedoras e poderem habitar uma democracia de uma forma mais séria (idem)

E mais adiante, continua:

De um ponto de vista estrito, não há propriamente universidade em Portugal. Ou seja, há excelente ensino universitário, há especialidades que são leccionadas e que treinam pessoas de modo excepcional, no domínio das engenharias, da medicina, da história; há vários domínios em que o treino é muito forte e muito bem feito. Mas esse treino é um treino vocacional. As pessoas fazem uma licenciatura monodisciplinar porque o desfecho dessa licenciatura - é sempre instrumental, aquilo serve para alguma coisa - é vocacional, é para eu exercer uma profissão (idem).

Fiz questão de apresentar esses excertos para ilustrar que ainda pode haver esperança para o ensino universitário brasileiro, caso nos esforcemos por implantar algo nesses moldes. Contudo, não sendo possível fazer isso em escala institucional, penso ser possível ao menos criar disciplinas com esse teor dentro das grades curriculares de todos os cursos oferecidos em nossas instituições. Novamente, eis um papel para o professor de Filosofia.

Voltando a Nóvoa, ele diz que, no curso em Estudos Gerais, a relação com o conhecimento é centrada em problemas, grandes temáticas e convergências, não tanto em disciplinas. Ora, essa ideia não é nova, retoma a concepção de inter(ou multi)disciplinaridade prezado pelo modelo de Humboldt.

Um contraponto à ameaça da "invasão empresarial" é conceber uma autonomia "virada para fora", não corporativista nem protecionista, no sentido da universidade não se encerrar em seus interesses e problemas internos. A universidade se coloca não apenas como produtora de bens gerados a partir de ciência e tecnologia "comerciável e lucrativa", mas como servidora do país, enquanto instituição participativa da vida civil. Seu maior bem é o aprofundamento da vivência democrática e da construção da responsabilidade pública. Ou seja, a universidade se apresenta como um exemplo de instituição virtuosa em termos éticos, intelectuais, políticos e científico, podendo, quiçá, influenciar o comportamento dos agentes empresariais que por ela rondam.

Para se contrapor ao "vício" da excelência acadêmica, é preciso dar o devido valor ao ensino, havendo reequilíbrio com a pesquisa. Mais do que isso, tem que haver forte ligação de ambos. Conhecimento de ponta e inovação são produzidos por poucos e para poucos, e é o ensino que faz a distribuição desse conhecimento, assim como a extensão o leva para fora da universidade. O ensino e a extensão também são partes da tão acalentada inovação. Graças à essa distribuição, os saberes são renovados e o círculo virtuoso do conhecimento segue seu vigor. Cabe também lembrar da natureza democrática da ciência - o conhecimento produzido nas universidades públicas, mesmo com a injeção de recursos privados, deve ser público, um bem comum.

A defesa da ciência básica, do tempo da investigação e da maturação do conhecimento e o compromisso público da universidade são contrapontos ao empreendedorismo enquanto critério para políticas educacionais. O empreendedorismo dentro das universidades não pode ganhar terreno como privatização de conhecimentos e de setores. O tempo do trabalho intelectual e da pesquisa científica são diferentes de uma linha de montagem 
industrial. Qualquer iniciativa empreendedora na universidade deve levar em conta a partilha do que é comum, a construção do comum, isto, daquilo que integra a cidade, o país e seus cidadãos.

Enfim, pelo que podemos ver nos noticiários e a partir da palestra de Nóvoa, temos que admitir que Portugal segue um tanto melhor e mais inovadores (a versão "subversiva" do termo) do que nós em termos de educação superior (política e economicamente também). Diante do desmantelamento de nossas universidades e dos discursos equivocados de uma parcela considerável de nossos concidadãos, resta-nos planejar e ir preparando o terreno para que algo semelhante à experiência da Universidade de Lisboa tenha a possibilidade de ser realizado no Brasil. Felizmente, como diz um grande amigo, "há-braços" para quem se engaja e persiste nessa tarefa.

As palavras do prof. António Nóvoa também corroboram a concepção de "conservadorismo universitário" que procurei caracterizar mais acima. Contudo, dar todos os créditos de minha esperança ao professor português seria injusto, haja vista que, há mais de 15 anos, convivo com pessoas brilhantes que vêm pensando sobre todas essas questões. Na verdade, a palestra de Nóvoa apenas reforçou a convicção de que nós estamos no caminho certo e lutando a boa luta.

\section{Considerações finais}

Assim como a Filosofia, a Universidade passa por constantes questionamentos sobre sua utilidade, de modo que precisamos recorrer às suas histórias (que se confundem) e, no caso da Filosofia, à investigações metafilosóficas. E a pergunta que costuma vir em primeiro lugar em nossos dias é a do "para quê". Mas isso não é tão ruim, uma vez que uma das perguntas metafísicas fundamentais é "qual o sentido da vida?" ou "para que estamos aqui?". Para mim, as perguntas e respostas sobre o valor e utilidade da Filosofia e da Universidade são igualmente fundamentais, pois ambas dão sentido a modos de vida e também proporcionam a "experiência de estar vivos". Tomo as palavras de Joseph Campbell para ilustrar a minha conviç̧ão:

Dizem que todos procuramos um sentido para a vida. Não penso que seja assim. Penso que o que estamos procurando é a experiência de estar vivos, de modo que nossas experiências de vida, no plano puramente físico, tenham ressonância no interior do nosso ser e da nossa realidade mais íntima, de modo que realmente sintamos o enlevo de estar vivos (CAMPBell, 1990).

Campbell se referia ao poder que mitos e metáforas têm sobre nós, na constituição de sentido que oferecem às narrativas através das quais damos sentido às nossas experiências.

Lançando mão de mitos e metáforas, recomendo aos estudantes todo o apreço à ideia da vida universitária como uma experiência de generosidade e com os vários sentidos do amor: Eros, Filia e Ágape. Grosso modo, as analogias e metáforas que tenho em mente poderiam ser entendidas assim: Eros $^{27}$ é o amor desejante, sempre na busca incessante e engenhosa por aquilo que lhe falta. Insaciável volúvel, egoísta. É o encontro de entidades que trocam prazeres, que se entregam ao outro, mas não totalmente. Eros cobiça e devora seu objeto, é capaz de consumir o outro por completo. Eros é o amor que rege a Pesquisa, a investigação científica - a relação entre o sujeito do conhecimento e o objeto do conhecimento na universidade. O amor físico, tátil, empírico

27 Como é bastante conhecido, na mitologia grega, Eros é o deus do amor, filho de Porus, o esperto, e Penia, a penúria. Porus é a personificação da riqueza; Penia, da pobreza. Concebido enquanto Porus e Penia estavam embriagados de néctar servido em uma celebração à Afrodite, deusa da beleza, Eros compartilha características de seus pais e é adorador da beleza. Por ser filho de Riqueza e da Pobreza, o Amor "é sempre pobre, e longe está de ser delicado e belo, como a maioria imagina, mas é duro, seco, descalço e sem lar, sempre por terra e sem forro, deitando-se ao desabrigo, às portas e nos caminhos, porque tem a natureza da mãe, sempre convivendo com a carência. Conforme o pai, porém, ele é insidioso com o que é belo e bom, e corajoso, decidido e enérgico, caçador terrível, sempre a tecer maquinações, ávido de sabedoria e cheio de recursos, a filosofar por toda a vida, terrível mago, feiticeiro, sofista: e nem imortal é a sua natureza nem mortal, e no mesmo dia ora ele germina e vive, quando enriquece, ora morre e de novo ressuscita, graças à natureza do pai; e o que consegue sempre lhe escapa, de modo que nem empobrece o Amor nem enriquece, assim como está no meio da sabedoria e da ignorância” (Platão, 1979, p.35). 
(o toque das mãos e dos olhos sobre os livros, o contato com os objetos de estudo e com os experimentos). O desejo e a busca pelo conhecimento na universidade não cessam, explora seus objetos de estudo ao máximo, está sempre insatisfeito com o que já tem. Uma vez se sentindo satisfeito ou encontrando obstáculos para seguir na sua exploração/investigação, a pesquisa vira seus olhos para outros objetos e, assim, segue o sentido de sua existência. Eros/Pesquisa não gosta de amarras, não consegue ser o que é nem se expressar sem a Liberdade (o valor da liberdade científica, liberdade de pesquisa).

Filia ${ }^{28}$ é o amor fraternal. A manifestação do amor da amizade, a alegria de estar com o amigo, a alegria da troca entre aqueles em quem confiamos, aqueles que escolhemos ou escolheram estar conosco. Há a alegria do diálogo. Filia é o Ensino - a relação entre mestres e aprendizes na vida acadêmica. É a relação generosa entre docentes e discentes na troca de conhecimentos e experiências. Filia é altruísta. Temos aqui um valor universitário imprescindível: a colaboração/cooperação. Filia/Ensino requer fraternidade e humildade intelectual.

Ágape, o amor da caridade, o amor generoso, incondicional, amor da entrega e do autossacrifício. Abraça os demais tipos de amor, pois é preciso ter uma medida de desejo pelo outro, mas não em nome do egoísmo, da carência, da necessidade ter a posse do que o outro tem de próprio. Ágape vai além de Filia, pois não precisa de laços afetivos tão estritos com o ser amado («filiado»). Ágape não se importa com quem é o ser amado, pois abarca a todos. "É amar/fazer o bem sem olhar a quem", como dizem. Ágape contrabalançaria a relação entre Filia/ensino e Eros/pesquisa. Atividade extensionista das universidades seria Ágape - expande o entrelaçamento entre Eros e Filia para além do local em que se dão. Ao mesmo tempo, mostra o valor das realizações e do modus operandi universitário de Eros/Pesquisa e Filia/Ensino. Ágape/Extensão preza pelo equilíbrio entre as demais partes, procura garantir a igualdade de valor e atenção entre aquilo que lhe é familiar e aquilo que se mostra como diferente (relação academia-sociedade). É lamentável que muitos jovens passem pela instituição sem conseguir vivenciar experiências positivas capazes proporcionar condições para compreenderem o sentido dessa ilustração.

Ainda pior é o fato de muitos sofrerem em sua passagem. Os motivos para tais sofrimentos são variados, complexos e, às vezes, tangenciam os limites do insondável. Em todo caso, conforme tentei demonstrar, emprego meus escassos recursos intelectuais, materiais e institucionais para reverter essa situação. Decerto, parte do sofrimento vem da própria preocupação do graduando a respeito de sua "empregabilidade" após formado, vem da insegurança em relação à escolha do curso, da impressão de inadequação à vida acadêmica, das pressões dos familiares para que ganhe independência financeira. Estas são fontes de angústia, mas insisto que a parte da solução tanto para a ansiedade, quanto para a insegurança esteja na aposta na "utilidade do inútil", no trabalho intelectual e conceitual básico, bem como na atenção às questões de ordem psicológico-cognitiva.

Por isso, elaborei a disciplina para familiarizar os estudantes com hábitos, habilidades e valores intelectuais do exercício do pensamento crítico, reflexivo e questionador distintivos da Filosofia e, logo, do modo próprio de se estudar na universidade. Espero que adquiram, ao final do curso, as atitudes e os instrumentos básicos não apenas para cumprir satisfatoriamente suas tarefas acadêmicas cotidianas - leitura, compreensão, análise, avaliação e composição de argumentos e textos -, como também para realizar reflexões e exercícios de autoconhecimento e autoaprimoramento (trabalho metacognitivo) ao longo de toda a sua formação universitária. Pode não ser o bastante como "terapia cognitivo-psicológica" (tampouco psicanalítica), mas creio que tudo isso seja vital para a formação, tal como diz o professor de filosofia Luiz Felipe Pondé: "formar alguém é dar a esta pessoa ferramentas necessárias para ela compreender melhor o mundo em que vive e poder, no mínimo, sofrer nomeando as razões de seu sofrimento"29. O trabalho sobre vieses cognitivos faz parte dessa preocupação com a formação. As mesmas considerações valem para as disciplinas sobre Universidade. Para mim, isso tudo é uma questão de compromisso epistêmico, axiológico e político.

Além de nomear as razões de nossos sofrimentos, vale todo o empenho e perseverança para nos dotar de competência e discernimento para projetar nosso futuro em meio à confusão e ao falatório. Citando Domenico De Masi:

28 Philia é um termo grego encontrado na obra "Ética a Nicômaco", de Aristóteles.

29 Extraído do prefácio escrito por Pondé para o livro "Marx estava certo"(2012), de Terry Eagleton. 
[...] situei a causa da depressão [universal] na desorientação, a causa da desorientação na impossibilidade de distinguir, a impossibilidade de distinguir na falta de um modelo de referência, de um paradigma capaz de fornecer ao nosso juízo critérios precisos de avaliação e, ao nosso itinerário, balizas seguras. Dessa concatenação de causas fiz descender a incapacidade individual e coletiva de projetar o futuro. E quando não somos nós a projetar nosso futuro, outros o projetam por nós, agravando a nossa sensação de impotência (DE MASI, 2017, P.11)

Convém não permitir que os financistas projetem sozinhos o futuro das universidades.

Vou insistir que, além de transmitir e produzir conhecimentos, de preparar profissionais para o mercado de trabalho, seria de grande valor se a universidade se engajasse no cultivo e no exercício da cultura e da sabedoria ("competências existenciais"), a despeito da falta de incentivos do Estado e da iniciativa privada (que, em geral, só interessa por pessoas enquanto forem consumidoras/clientes, e não cidadãs). Portanto, a formação universitária plena conectaria edificação pessoal e formação profissional, assim como proporcionaria educação científico-tecnológica com base humanística ${ }^{30}$. Citando Nuccio Ordine mais uma vez:

Seria absurdo colocar em dúvida a importância da preparação profissional nos objetivos das escolas e das universidades. Mas a tarefa da educação pode ser realmente reduzida à formação de médicos, engenheiros e advogados? Privilegiar exclusivamente a profissionalização dos estudantes significa perder de vista uma dimensão universal da função formativa da educação: nenhuma profissão poderia ser exercida de modo consciente se as competências técnicas que ela exige não estivessem subordinadas a uma formação cultural mais ampla, capaz de encorajar os alunos a cultivarem autonomamente seu espírito e a possibilitar que expressem livremente sua curiositas. Equiparar o ser humano exclusivamente com sua profissão seria um erro gravíssimo... (ORDINE, 2016)

Qualquer universidade que privilegia apenas a profissionalização não serve para coisa alguma e para ninguém, a não ser que sejamos proprietários de universidades privadas e/ou acionistas da Kroton Educacional.

Neste texto, procurei contar parte da minha história para ilustrar as razões e as motivações para eu defender que viver a ideia de Universidade é algo bom, único e valioso, seja qual for o significado que se dê à universitas: como "corporação", "entidade que consiste em humanos reunidos em um projeto de duração indefinida cujas metas suplantam as metas individuais porque o projeto em si é visto como alguma coisa que possui valor intrínseco" (Fuller, 2010, p. 27. Tradução minha); ou como locus de "unicidade (Uni-) da existência social e historicamente efetiva de diferenças (versus). (Schneider, 2002, p.359). O que importa é preservá-la como fonte de experiências transformadoras e protegê-la das abordagens administrativas-economicistas sobre as manifestações e o comportamento humanos.

Para compor esta exposição, recorri não apenas a trabalhos acadêmicos, mas também a materiais recolhidos em blogs, documentários, revistas de divulgação científica e palestras. Há uma grande quantidade de artigos e livros acadêmicos sobre o tema, e eu não pretendi tentar fazer mais uma revisão de literatura, ou diagnósticos e prognósticos, ou projetos para reformas jogado nas redes da internet. Uma das intenções desta contribuição ao dossiê "Universidade e Utilidade" foi expor ideias e indicar material bibliográfico para que o leitor seja capaz de buscar suas próprias concepções sobre o tema e seguir adiante. Como o leitor pode admitir, fui fiel ao tom informal e espero ter tornado a leitura mais pessoal e amistosa para o público em geral, especialmente às calouras e aos calouros das universidades públicas. Foi a eles que me dirigi ao longo da exposição.

30 Um dos objetivos registrados pelo idealizador e fundador da UENF, Darcy Ribeiro, no Plano Orientador dessa universidade. Cf. Ribeiro, 1993. 


\section{Referências Bibliográficas}

ARENDT, Hanna. A Crise da Educação. Disponível em: http://www.gestaoescolar.diaadia.pr.gov.br/arquivos/File/otp/ hanna arendt crise educacao.pdf Acessado em 26 de agosto de 2017

BARBOSA, Ricardo; Videira, A.A.P. “Autonomia e liberdade na vida universitária”. in Revista Ciência Hoje Vol. 36., p 33-35.

BRAGA, Miguel. Quando a ignorância gera confiança (o efeito Dunning-Kruger). Disponível em: http://blog.miguelbraga.net/quando-a-ignorancia-gera-confianca-o-efeito-dunning-kruger. Acessado em: 02/01/2014.

CAMPBELL, Joseph; Moyers, B. O poder do Mito. Tradução de Carlos Felipe Moisés. São Paulo: Palas Athena, 1990

CASPER, Gerhard; Humboldt, W. von. Um mundo sem universidades? Trad.: Johennes Kretschner e João Cezar de C. Rocha. Rio de Janeiro: EdUERJ, 2003.

CHAUÍ, M. Escritos sobre a Universidade. São Paulo: Editora UNESP, 2001

CERCHIARI, Ednéia Albino Nunes et al. Prevalência de transtornos mentais menores em estudantes universitários. Estudos de Psicologia (Natal), 2005.

CLANCE, Pauline R.; Imes, Suzanne. The Imposter Phenomenon in High Achieving Women: Dynamics and Therapeutic Intervention. Psychotherapy Theory, Research and Practice Volume 15, n. 3, 1978.

DE MASI, Domenico. Alfabeto de sociedade desorientada. São Paulo: Objetiva, 2017.

DE MELO CAVESTRO, Julio; Rocha, Fabio Lopes. Prevalência de depressão entre estudantes universitários. J Bras Psiquiatr, v. 55, n. 4, p. 264-267, 2006.

DORIA, Francisco Antonio (coord.) A crise da universidade. Rio de Janeiro: Revan, 1998.

DUTRA, Elza. Suicídio de universitários: o vazio existencial de jovens na contemporaneidade disponível em http:// www.revispsi.uerj.br/v12n3/artigos/html/v12n3a13.html Acessado em 17 de agosto de 2017.

DUNNING, David. We are all confident idiots. Pacific Standart: The Science of Society. October, 2014.

EHRLINGER, Joyce; JOHnson, Kerri; BANNER, Matthew; et al. Why the unskilled are unaware: Further explorations of (absent) self-insight among the incompetent. Organ Behav Hum Decis Process. 2008 January1; 105(1): 98-121.

FÁVERO, Altair A. Políticas educacionais e os desafios da universidade no século XXI. In: AlmEIdA, Maria de Lourdes Pinto de; Mendes, Vitor Hugo (orgs.). (Des) Construção da universidade na Era do "pós": tensões, desafios e alternativas. Campinas, SP: Mercado de Letras, 2010, p.81-98.

FREITAS, Maria E. A carne e os ossos do ofício acadêmico. Revista Organização e Sociedade. Salvador, UFBA, v.14, n.42, jul/set., p.187-191, 2007

FULLER, S. Science. Durham, UK: Acumen Publishing Limited, 2010.

GUEST, Matthew. Can universities still provide a transformative experience? 2016 Disponível em https://www.opendemocracy.net/transformation/mathew-guest/can-universities-still-provide-transformative-experience Acessado em Fevereiro de 2017.

HALFFMANN, Willem; RAdDer, Hans. Manifesto Acadêmico: de uma universidade ocupada a uma universidade pública. Tradução: Tamires Cianci von Atzingen, Carlos Machado e Marcos Barbosa de Oliveira. Revista Adusp. Maio de 2017, p.6-25.

HERRMANN, Rachel. Impostor Syndrome Is Definitely a Thing. Disponível em: http://www.chronicle.com/article/ Impostor-Syndrome-Is/238418 Acessado em Abril de 2017.

HUANG, Sui. When peers are not peers and don't know it: the Dunning-Kruger effect and self-fulfilling prophecy in peer-review. Bioessays 35, 2013, p. 414-416.

KAHNEMAN, Daniel. Rápido e Devagar: Duas formas de pensar. Rio de Janeiro: Editora Objetiva, 2012.

KRUGER, Justin; DUNnING, David. Unskilled na Unaware of It: How Difficulties in Recognizing One’s Own Incompetence Lead to Inflated Self-Assessments. Journal of Personality and Social Psychology. 1999, Vol. 77, No. 6. $121-1134$.

MACHADO, Ana M. Netto; Mendes, Vitor Hugo. Revisitando as concepções de Willhem Von Humboldt em torno da universidade: o que dizer duzentos anos depois? In: Almeida, Maria de Lourdes Pinto de; Mendes, Vitor Hugo (orgs.). (Des) Construção da universidade na Era do "pós": tensões, desafios e alternativas. Campinas, SP: Mercado de Letras, 2010. P. 15-38. 
MCRANEY, David. Você não é tão esperto quanto pensa. Trad: Marcelo Barbão. Editora Leya. São Paulo, 2012.

MENDONÇA, André Luiz de O. Dos Valores de Medida aos Valores como Medida: Uma avaliação axiológica da avaliação acadêmica. Ensaios Filosóficos, Volume X - Dezembro/2014, p. 111-133.

JOSEPH, Miriam. O Trivium: entendendo a natureza e a função da linguagem. São Paulo: É Realizações Editora, 2014.

MIGUEL, L. R.. Resenha do livro Schwartzman, Simon (Org.) A educação superior na América Latina e os desafios do século XXI. Em Construção. ano 1, No. 1, 2017, pp. 165-178. DOI:10.12957/emconstrucao.2017.28131

OLIVEIRA, Aercio Barbosa de. Originalidade e inovação na filosofia das ciências contemporânea: ainda faz sentido tratá-las como termos distintos? 2015. 158p. Dissertação (Filosofia) - Universidade do Estado do Rio de Janeiro. Orientador: Antonio Augusto Passos Videira.

OLIVEIRA, Carla et al. Programas de Prevenção para a Ansiedade e Depressão: Avaliação da Percepção dos Estudantes Universitários. Interacções, v. 12, n. 42, 2017.

ORDINE, Nuccio. A utilidade do inútil: um manifesto. Rio de Janeiro: Zahar Editora, 2016, Versão Kindle.

PAUL, Richard.; ELDER, Linda. Critical thinking: concept and tools. 2006. Disponível em https://www.criticalthinking. org/files/Concepts Tools.pdf Acessado em Dezembro de 2016.

PLATÃO. O Banquete. Tradução de José Cavalcante de Souza. São Paulo: Abril Cultural, 1979, p.35.

PEDROSA, Renato H.L.. Inovação tecnológica e a "terceira missão" da universidade. In: SchwARTZMAn, S. (org.) A educação superior na América Latina e os desafios do século XXI. Campinas, SP: Editora da Unicamp, 2014, p. 219-282.

RIBEIRO, Darcy. A Universidade Necessária. Rio de Janeiro: Paz e Terra S.A., 1979.

Universidade para quê? Brasília: Editora Universidade de Brasília, 1986.

. Plano Orientador das Universidade Estadual Norte Fluminense" In: Universidade do Terceiro Milênio. Rio de Janeiro: UENF, Vol. 1, n. 1, 1993.

RIBEIRO, Raquel. Estudos Gerais é um curso para curiosos inquietos. 2014 Disponível em: https://www.publico. pt/2014/09/14/portugal/noticia/estudos-gerais-e-um-curso-para-curiosos-inquietos-1669347 Acessado em 21 de agosto de 2017.

REIS, Verusca M.S.dos; VIDEIRA, A.A.P.. John Ziman e a ciência pós-acadêmica: consensibilidade, consensualidade e confiabilidade. Scientice Studia, São Paulo, v. 11, n. 3, p. 583-611, 2013.

ROITMAN, Janet. Anti-Crisis. Durham, North Carolina: Duke University Press, 2014

SAMPAIO, Helena. Privatização do ensino superior no Brasil: Velhas e novas questões. In: SchwARTZMAN, S. (org.) A educação superior na América Latina e os desafios do século XXI. Campinas, SP: Editora da Unicamp, 2014, p. 139-192.

SANTOS, Boaventura de S. Pela mão de Alice: o social e o político na pós-modernidade. São Paulo: Cortez, 2013

SCHWARTZMAN, S. A educação superior e os desafios do século XXI: Uma introdução. In: SCHWARTZMAN, S. (org.) A educação superior na América Latina e os desafios do século XXI. Campinas, SP: Editora da Unicamp, 2014, p. 15-44.

TRINDADE, Hélgio. "As metáforas da crise: da 'universidade em ruínas" às "universidades na penumbra" na América Látina”. In Gentili, Pablo (org.). As universidades na penumbra: neoliberalismo e reestruturação universitária. São Paulo: Cortez, 2001.

WATERS, Lindsay. Inimigos da esperança: publicar, parecer e o eclipse da erudição; tradução de Luiz Henrique de Araújo Dutra. - São Paulo: Editora da UNESP, 2006. 